NBER WORKING PAPER SERIES

\title{
HOUSEHOLD LEVERAGE AND THE DEDUCTIBILITY OF HOME MORTGAGE INTEREST: EVIDENCE FROM UK HOUSE PURCHASERS
}

\author{
Patric H. Hendershott \\ Dr. Gwilym Pryce \\ Dr. Michael White \\ Working Paper 9207 \\ http://www.nber.org/papers/w9207
NATIONAL BUREAU OF ECONOMIC RESEARCH
1050 Massachusetts Avenue
Cambridge, MA 02138
September 2002

An earlier version of this paper was presented at the American Real Estate and Urban Economics Association 2002 Meetings in Atlanta. We thank our discussant, Gary Engelhardt, for helpful comments. The views expressed herein are those of the authors and not necessarily those of the National Bureau of Economic Research.

(C) 2002 by Patric H. Hendershott, Dr. Gwilym Pryce and Dr. Michael White. All rights reserved. Short sections of text, not to exceed two paragraphs, may be quoted without explicit permission provided that full credit, including (C) notice, is given to the source. 
Household Leverage and the Deductibility of Home Mortgage Interest: Evidence from UK House Purchasers

Patric H. Hendershott, Dr. Gwilym Pryce, and Dr. Michael White

NBER Working Paper No. 9207

September 2002

JEL No. H2

\section{$\underline{\text { ABSTRACT }}$}

During the last quarter century, mortgage interest deductibility has been gradually phased out. In 1974 a ceiling was set on the size of the mortgage eligible for interest deductibility ( $£ 30,000$ since 1983$)$, and, beginning in 1993, the maximum rate at which interest under that ceiling could be deducted was reduced in four steps to zero in 1999. The combination of these changes gives a rich array of different debt tax penalties for different households in different years. We analyze over 117,000 loans originated in the UK during the 1988-91 and 1995-98 periods to finance home purchases. We first estimate a logit to predict whether a household's loan exceeds the $£ 30,000$ ceiling. These predicted probabilities are then employed to construct debt tax penalty variables that are used to explain household LTVs on loans to finance home purchases. The penalty variables depend on the predicted probability of having a loan that exceeds the ceiling, the market mortgage rate, and exogenous household specific tax rates. From these results we compute estimates of the impact of removing deductibility on initial LTVs in the UK and on the weighted average cost of capital for owner-occupied housing. Removal of deductibility is estimated to reduce initial LTVs, which mitigates the rise in the weighted average cost of capital, by about 30 percent, with the reduction varying with household age, loan size (above or below the $£ 30,000$ limit) and tax bracket.

Patric H. Hendershott

Aberdeen Business School

University of Aberdeen

Aberdeen AB24 3UF

phh3939@uslink.net
Dr Gwilym Pryce

Department of Urban Studies

University of Glasgow

Glasgow G12 8RS

g.pryce@socsci.gla.ac.uk
Dr Michael White

Department of Land Economy

University of Aberdeen

Aberdeen AB24 3UF

m.white@abdn.ac.uk 


\section{Household Leverage and the Deductibility of Home Mortgage Interest: Evidence from UK House Purchasers}

\section{Introduction}

Periodically people propose removal of the home mortgage interest deduction in the U.S. (Follain and Melamed, 1998). The primary motivation for such proposals is recapture of tax revenue lost by the deduction - it is a major "tax expenditure." According to Follain and Melamed the official annual expenditure in the middle 1990 s was $\$ 40$ to $\$ 50$ billion. ${ }^{1}$ Numerous advocates would prefer to use these funds in a multitude of different ways. A secondary argument for removal of the deduction is that the expenditure is sharply skewed toward higher income households who are more likely to be homeowners and to finance large houses.

On the other hand, the mortgage interest deduction encourages home ownership and others argue that home ownership provides many positive externalities and thus ought to be encouraged. These include that ownership leads households to better maintain their dwellings and to raise children that do better on achievement tests and have fewer behavioral problems (Haurin, et. al., 2002). Moreover, eliminating the mortgage interest deduction wouldn't remove the fundamental tax advantage to home ownership - the favorable tax treatment of capital gains and imputed rents (Hendershott and Slemrod, 1983), but would just restrict the advantage to wealthy households that do not need to use debt finance (Woodward and Weicher, 1989).

This paper is not about the appropriateness of the mortgage interest deduction. Rather it is about the impact of the deduction on the use of debt to finance house purchases. This topic is crucial to both the amount the deduction lowers government tax revenue and the impact of deductibility on homeownership. If households were to sell taxable bond holdings to mortgage lenders and pay off their entire mortgage debt in response to elimination of deductibility, the government would gain no tax revenue and the cost of financing home ownership would be unchanged (assuming households and lenders pay the same tax rate). Portfolio reallocations with no real or tax consequences would be the sole result. At the other extreme, if households

\footnotetext{
${ }^{1}$ Inland Revenue estimated the expenditure to be nearly $£ 8$ billion in 1990/91 (Devereux and Lanot, 2001, p 2).
} 
did not reduce their leverage, their after-tax income would fall and both the cost of homeownership and government tax revenues would rise significantly. Estimating where between these polar extremes household behavior lies is the purpose of this paper.

The fundamental tax advantage to owner-occupied housing is the generally low taxation of the return on the equity invested in the house (Hendershott and White, 2000). Few countries tax capital gains (the U.S. excludes the first $\$ 500,000$ in gain), and, while a few European countries tax imputed rents (the U.S. does not), they are taxed at lower effective rates than private market rents are taxed. The magnitude of the fundamental tax advantage is directly related to the levels of both nominal pretax asset returns in the economy and household marginal income tax rates. The higher the level of returns and/or tax rates, the more valuable is the low taxation of the returns on owner-occupied housing. Because the tax advantage increases as the marginal tax bracket of the household increases, the demand for owner-occupied housing is greater the higher the tax bracket of the household (holding after-tax income constant). The housing tax advantage is clearly less in countries with flat (low) tax rate schedules.

In the quarter century after 1938, the UK sharply reduced the relative taxation of equity-financed owner-occupied housing. ${ }^{2}$ When income taxation was reintroduced in 1842 , imputed rent was set equal to an assessed value, which equalled an estimate of market rate and was taxed under 'Schedule A' of the income tax system, and mortgage interest (all household interest payments) was fully deductible (Hills, 1991). Reassessments were made every five years until 1935. By 1961, when the next reassessment was undertaken, imputed rent had been eroded by inflation to only a third of market rent. In 1963 the Conservative Government abolished taxation of imputed rents altogether, increasing and making permanent the low taxation of this component of return. The tax advantage to the capital gains component of return commenced when the capital gains tax, introduced in 1965, exempted gains on owner-occupied housing.

The deductibility of home mortgage interest is a means of extending the fundamental tax advantage of owner-occupied housing, the low taxation of the return on equity invested in housing, to the numerous younger, less wealthy households who cannot finance their purchase entirely with equity. Most developed

\footnotetext{
${ }^{2}$ During the 1980s the UK and many other countries sharply increased the relative taxation of equityfinanced owner-occupied housing by significantly cutting the tax rates applied to other capital income.
} 
countries allow a mortgage interest deduction, although many European countries limit it to a fixed amount or allow the deduction to be taken only at a tax rate less than that of many household marginal rates. In contrast, the Commonwealth countries -- Australia, Canada, New Zealand and now the UK - do not allow this interest deduction.

In fact, interest has never been fully deductible in the U.S. Low income households or households with low mortgage debt living in states with low house prices and low taxation (state taxes and mortgage interest are the two largest deductible expenses) would select not to itemize expenses because taking the standard deduction would lower their taxes (Ling and McGill, 1998). Further, even if a household did itemize, not all mortgage interest was effectively deductible (the amount of interest that raised total deductible expenses to the standard deduction was "wasted"). The amount of wasted interest (and the number of households that chose not to itemize) grew following the 1986 tax act for two reasons (Hendershott, Follain and Ling, 1987). First, a number of expenses that were previously deductible could no longer be itemized, probably the most important being the interest on consumer credit debt. Second, the standard deduction was sharply increased. The 1986 act also phased out itemized deductions when household income rose above threshold levels, limiting deductibility for very high income households to as little as 20 percent of their interest paid.

Follain, Ling, and various associates have used the change in the effective deductibility of mortgage interest induced by the 1986 tax act to test the hypothesis that household leverage is sensitive to the tax penalty associated with debt (Follain and Ling, 1991, Ling and McGill, 1998, Follain and Dunsky, 1997, and Dunsky and Follain, 2000). In each case, the leverage of individual households was found to be related significantly to the effective deductibility of mortgage interest. This work, which requires forecasting various unavailable household expenses and determining whether households would select to itemize or take the standard deduction, is innovative indeed. Using the Dunsky and Follain estimates, Follain and Melamed (1998) built a simulation model and predicted that removal of the mortgage interest deduction would lower mortgage debt by 41 percent. 
The 41 percent estimate is roughly consistent with the aggregate comparison between Australia (AU) and the U.S. made by Capozza, Green and Hendershott (1996). They relate the LTVs of nearly 12,000 U.S. households in the 1989 Survey of Current Finances to the age of the household head and the log of income. This mimics the LTV estimates of Bourassa and Hendershott (1994) for just over 4,000 Australian households in 1986. Because interest is not deductible in Australia and is in the U.S., one would expect that the LTVs would be lower at all ages in Australia than in the U.S., and they are. The predicted U.S. (and AU in parentheses) LTVs for households of ages 25-29, 40-44, and 55-59 are $0.56(0.42), 0.34(0.12)$ and 0.16 (0.01).

Mortgage interest in the UK was fully deductible until 1974. At that time, a $£ 25,000$ ceiling was introduced on the size of mortgage eligible for interest deductibility. Given that the mean house price was $£ 10,000$, this ceiling affected few households. But because the ceiling was not indexed, it became progressively more binding over time as nominal house prices rose, and by 1990 it affected half of purchase loan originations. In addition, in 1993 the tax rate at which interest on debt below the ceiling could be deducted was lowered below the maximum rate at which income was taxed. In 1999 this rate was lowered to zero; deductibility was thus eliminated altogether.

The 1988-98 period of gradual removal, where households faced substantially different degrees of deductibility, is an ideal period to study the sensitivity of homeowner leverage to the deductibility of interest and to draw some inferences about the likely impact of the removal of interest deductibility on debt usage and the weighted average cost of capital for owner-occupied housing. Such is the goal of the present paper.

The remainder of the paper is divided into three sections and a conclusion/summary. We first derive debt tax penalty variables and present our estimation strategy. We then describe our database, including how we deal with credit rationing. Finally, we report our results based upon 1988-91 and 1995-98 loan samples.

\section{The Debt Tax Penalty and Form of the Estimation Equations}

As noted above, mortgage interest deductibility is a means of extending the fundamental tax advantage of owner-occupied housing to households who use debt finance. Deductibility does not 
make debt cheaper than equity, rather it maintains tax equality between the two costs. Thus to the extent that the deduction is limited, there is a tax cost or penalty to using debt and usage should be less.

\section{Measurement of the Tax Penalty on Debt}

This argument can be formalized in the following way. In general, the weighted average cost of capital for owner-occupied housing is just an average of the debt (CD) and equity (CE) costs where the weights are the loan to value ratio, LTV, and 1-LTV:

$$
\mathrm{WACC}=\mathrm{LTV}(\mathrm{CD})+(1-\mathrm{LTV})(\mathrm{CE}) .
$$

If the costs, $\mathrm{CD}$ and $\mathrm{CE}$, both equal the after-tax interest rate, $(1-t) \mathrm{i}$, then WACC $=(1-\mathrm{t}) \mathrm{i}($ we abstract from risk premia). However, if a tax penalty (pen) is imposed on debt usage, its cost is (1-t+pen)i and

$$
\mathrm{WACC}=(1-\mathrm{t}) \mathrm{i}+\mathrm{LTV}(\text { pen }) \mathrm{i}
$$

If the penalty is the nondeductibility of interest, $\mathrm{pen}=\mathrm{t}$ and the WACC is increased by the product LTVti.

How much the imposition of the tax penalty raises the WACC depends on how much households change LTV in response to the loss of deductibility. The more households reduce LTV, the less the cost is increased and thus the less will be the reduction in homeownership and housing demand. (Also, the less revenue the government will gain by imposing the tax penalty.) Estimating the LTV response is the primary purpose of this paper.

During the last quarter century, the mortgage interest deduction in the UK has been limited in two ways. First, in 1974 the deduction was restricted to that on a $£ 25,000$ mortgage (and the deductibility of interest on other household debt was eliminated). In 1983, the limit was raised to $£ 30,000$; the median UK house price level had nearly tripled to $£ 29,400$ since 1974 . Subsequently the limit was never again raised in spite of rising house prices (the median tripled again to $£ 87,300$ in 1999). As can be seen in Table $1 \mathrm{~A}$, by 1988-91 about half of the new mortgage originations were above the limit and by 1995-98 two-thirds were. Second, the maximum tax rate at which interest could be deducted was cut from the 40 percent maximum income tax rate to 25 percent in 1992 , to 20 percent in 1994, to 10 percent in 1995, and finally to zero in 1999. Given that there were only two household income tax brackets during this period, 25 and 40 percent, 
after 1993 no household paying taxes could deduct mortgage interest at their full marginal income tax rate (see Table 1B).

Of the ceiling and tax rate maximums, the former has been far more important for new borrowers who have reasonably high initial loan-to-value ratios (the average of our sample is about 0.75 ). With a median house price in $1995-98$ of $£ 60,000$ to $£ 70,000$ outside the London/Southeast area and $£ 85,000$ to $£ 115,000$ in London and the Southeast, most households had initial loans above the $£ 30,000$ mortgage limit and thus could not deduct interest at the margin.

Figure 1 illustrates how the debt tax penalty varies with loan size. Tax rates are on the vertical axis and loan amount on the horizontal. The top line is a household's marginal tax rate. Holding house value constant, the larger is the mortgage loan, the more interest is deductible (unless the loan is above the ceiling, Lc), but the larger are the household's taxable investments and thus the higher is its taxable interest income. As long as the ceiling isn't binding, taxable income is at least roughly independent of loan size. But when the loan exceeds the ceiling, the larger is the loan (and thus taxable investments), the higher is the household's taxable income. At some point the household could be pushed into a higher tax bracket, as the shift from $t 1$ to 2 illustrates.

Figure 1: The Tax Penalty Variable

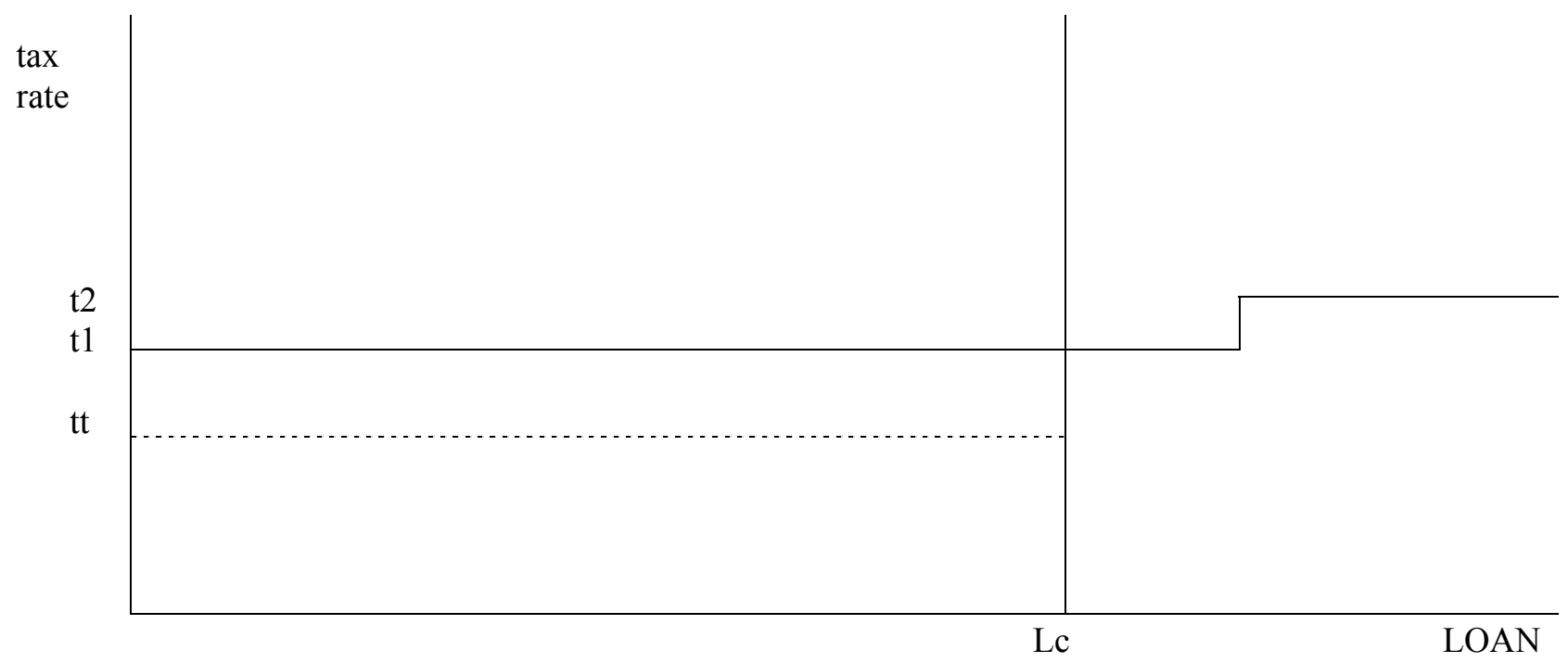


The dashed tt line in the figure indicates the lower maximum tax rate introduced in 1993 at which mortgage interest on the loan amount below the ceiling can be deducted. Of course, interest on the loan above the ceiling is deductible at a zero rate. To summarize then, the tax penalty on loans above the ceiling is the full tax rate, $\mathrm{t}$; the penalty below the ceiling is the maximum of $\mathrm{t}$-tt or zero (the latter for households with $\mathrm{t}<\mathrm{tt}$ ). Before 1993, there was no penalty on loans below the ceiling.

Thus two tax penalty variables are needed to reflect possible UK limitations on interest deductibility. The first captures the nondeductibility of interest on loans above the loan ceiling and is measured as the product of the tax rate and the market interest rate. The second captures the effect of the lower tax rate at which interest below the ceiling is deductible after 1992 and is measured as the product of $\max (\mathrm{t}-\mathrm{tt}, 0)$ and the market interest rate.

\section{Estimation Strategy}

To disentangle the characteristics of borrowers that have loans above the ceiling from characteristics that are caused by being above the ceiling, we first estimate a logit equation predicting whether or not the borrower's loan amount exceeds the ceiling and then use the predicted probability that the loan amount exceeds the ceiling, rather than whether it actually does, in computation of the tax penalty variables for use in the leverage estimation. This is an attempt to address the simultaneous determination of the tax penalty facing the borrower and his/her loan to value ratio. Although similar variables appear in both the LTV regression and the logit, we use different transformation of them in each. Combined with the non-linearity of the logit and the non-linear way in which the predicted probability enters the LTV regression, the incidence of multicolinearity between the tax variable and the other variables is minimized. The plausible signs and magnitudes of coefficients, the stability of the regressions and the high t-ratios confirm that multicolinearity is not a problem (Greene, 1993, p. 267).

The logit equation takes the form: 
$\operatorname{CEIL}(0 / 1)=\mathrm{f}($ income, ageDUMs, previous-owner, regionDUMs, yearDUMs $)$,

where income and previous owner are both entered separately and interacted with the age dummies $(<25,25-$ $34,35-44,45-54,>54)$. Income and age give us a prediction of housing demand by the household; the greater this demand, the more likely the loan is to exceed the ceiling. The impact of previous owner is unclear. On the one hand, a household with equity from a previous house can use this to make a larger down payment and thus would be less likely to have a loan above the ceiling. On the other hand, holding income, age, etc. constant, the more equity from a previous house, the larger can be the house one purchases. The regional dummies are introduced to reflect the impact of differences in regional house prices, and the year dummies are introduced to capture the variation in the level of house prices across the years of origination. The higher are house prices, the more likely is the ceiling to bind. Two equations are estimated, one for loan originations in "low" house price regions and another for those in "high" house price regions (see the data section).

The leverage estimation equation is:

$$
\operatorname{lnLTV}=\mathrm{g}[\text { basic determinants }]-\gamma \text { tiprob }-\beta \max (\mathrm{t}-\mathrm{tt}, 0) \mathrm{i}(1-\mathrm{prob})
$$

where prob is the predicted probability of having a loan above the ceiling. We allow for the tax penalty responses, $\gamma$ and $\beta$, to vary with the borrower's age. We denote the first tax penalty variable by T_above and the second by $\mathrm{T}_{-}$below.

The household tax rate used in this estimation, $t$, must be independent of LTV. We compute the tax rate on the first dollar of housing finance (opportunity cost of own equity invested unless the house is 100 percent debt financed) by adding an estimate of the income the household would have earned on the equity 
invested in the house, $\mathrm{i}($ HOUS-LOAN), to reported income. Given a progressive tax system, this is the highest possible estimated tax rate. ${ }^{3}$

\section{Data Base}

We use the Council of Mortgage Lenders (CML) 5\% random sample of mortgage loan origination data, which has 20,000 to 40,000 loans per year. The underlying database contains all loans originated by commercial banks, building societies and others. The data have been collected annually since 1974 . The key variables included in the CML data set are:

1. mortgage data: date, amount, type, initial rate, maturity, amortization pattern, and type of advance (whether new mortgage, re-mortgage, further advance, or top-up loan).

2. dwelling data: purchase price, location of house, and dwelling characteristics

3. borrower data: number, income and age of borrowers; previous tenure of main borrower.

A wide variety of mortgages exist in the UK, with product varying by repayment (standard, interestonly and endowment), term, and adjustment period. The major types of repayment are interest-only, fully amortizing, and endowment. The endowment mortgage is interest only, but the homeowner purchases a life insurance policy with a constant monthly premium that presumably will cover repayment at the end of the mortgage. ${ }^{4}$ The adjustment periods are monthly or fixed for various lengths. We have much detail on the 1995-98 loans, but less for 1988-91. Between the periods, the mean mortgage term fell from 23.4 to 20.5 years. The percentage of loans that were fully amortizing rose from 17 to 40 percent and interest-only increased from less than 4 to 19 percent. Endowment loans, on the other hand, fell from 62 to 37 percent. In 1995-98, two thirds of the loans were fully variable, while few were fixed for as long as five years.

\footnotetext{
${ }^{3}$ The Institute for Fiscal Studies at Cambridge University has the UK tax rules back to 1973 posted on its web site (www.ifs.org.uk). This information is used to compute the t's for our households. ${ }^{4}$ See Devereux and Lanot (2001) for an analysis of household choice between endowment and other mortgages.
} 
We analyze new mortgage data (mortgages to finance house purchases) from 1988-91 and 1995-98. ${ }^{5}$

By dealing with house purchasers, we avoid the problems of controlling for or estimating how long it will take existing owners to adjust their leverage level in response to changes in interest deductibility (Ling and McGill, 1998). The two time periods differ both in levels of house price (percent of loans over $£ 30,000$ ) and in the debt tax penalty. During $1995-98$, mortgage interest on loans below the $£ 30,000$ ceiling was deductible at the 10 percent rate $\left(t^{*}=0.1\right)$, rather than the marginal income tax rate of most households. Thus the tax rate penalty was either 0.3 or 0.15 for households with loans below the ceiling versus 0.4 or 0.25 for households above the ceiling. During the 1988-91 period, the tax penalty varied from zero for households with loan size less than the ceiling to the highest marginal tax rate of households with loan size greater than the ceiling. Given that the tax penalty was less dependent on whether one is above or below the ceiling in 1995-98 than in 1988-91, estimates from the latter period will be less dependent on the accuracy of the estimated logit than estimates from the earlier period.

Figure 2 plots constant-quality UK house prices for 10 regions over the period 1980 to 1998 . Prices grew steadily (nearly 10 percent per annum) during the 1970s and 1980s and were relatively flat during the 1990s. ${ }^{6}$ At all times prices in London and the Southeast are significantly greater than those in the rest of the UK, and during the late 1980s prices in the Southwest and East Angelica were also relatively high. Loans from these four areas are designated the high price group and loans from the other regions are labelled the low price group during the 1988-91 period. Only London and the Southeast are classified as high house price areas during the 1995-98 period. Because households in high house price areas are far more likely to have loans above the $£ 30,000$ ceiling, we estimate separate logit equations for data in the high and low price

\footnotetext{
${ }^{5}$ In 1988 the deductibility of interest on loans for renovation was eliminated, as was the ability of both members of an unmarried couple to deduct interest on loans of up to $£ 30,000$ (removing a then existing "marriage tax penalty" by increasing the tax on non-marrieds). Prior to 1988 it is difficult to determine whether a multiple-adult household faced a $£ 30,000$ or $£ 60,000$ fully deductible ceiling.

${ }^{6}$ The movement in real house prices is substantially different. In particular, real prices cycled sharply during the 1972-76 and 1985-93 periods and otherwise grew at a fairly steady 2.5 percent between 1970 and 1997. This 2.5 percent barely exceeds the two percent drift in the U.S. that Hendershott and Thibodeau (1990) attribute to new houses being of higher quality than old and old being renovated. That is, median house price inflation exceeds constant-quality house price inflation by two percent annually.
} 
areas. Because we believe it especially important to analyze samples with wide variation in the debt tax penalty, we estimate a single equation for each period to explain household LTVs.

We restrict the data set in a number of ways. First, to exclude investment properties we delete loans to finance houses not occupied by the borrower. Second, we delete observations owing to missing values for some of the variables needed for the logit estimations. Third, we eliminate borrowers who are deemed likely to have had their borrowing decision dictated by lender borrowing limits (borrowers who are at/near the maximum allowable loan-to-value and/or loan-to-income ratios). Constrained borrowers are unlikely to be able to respond to the tax penalty.

The deletion of credit-constrained borrowers involves three steps. First, we identify a clearly unconstrained subset of borrowers. Second, we estimate housing demand functions for these households. Third, we predict housing demand for the rest of the sample (the possibly constrained borrowers). Borrowers with demand equal to or greater than that predicted are defined as unconstrained and added to the clearly unconstrained to form our total sample. Sample selection effects were captured using the Heckman estimation procedure. Here we discuss how the clearly unconstrained subset was identified. The housing demand estimation is contained in the Appendix.

Figures 3 and 4 contain the distributions of loans by LTV between zero and unity (the top half) and then between 0.8 and 1.0 (the bottom half) in our 1988-91 and 1995-98 samples (high and low priced regions are similar). The concentration of borrowers at the 90 and especially 95 and 100 percent values in the earlier period is obvious. This reflects both the increase in borrowing costs (required default insurance contracts) as those values are exceeded and, for the 100 percent concentration for sure, the maximum loan that lenders will make. The deregulation of financial institutions in the early 1980s had a major impact. In 1979, less than four percent of loans with LTVs above 80 percent had LTVs over 95 percent and only 20 percent had loans over 90 percent. In our full database, over a quarter of such loans had LTVs over 95 percent and two-thirds had them above 90 percent.

Figure 4 suggests a tightening of the LTV maximum in the middle 1990s; very few loans with LTV above 95 percent were originated in the 1995-98 period, while 15 percent of 1988-91 loans had LTVs of 100 
percent. Nonetheless, in the later period 75 percent of loan originations had LTVs above $80 \%$, versus only 57 percent in the $1988-91$ period. That is, while there was a sharp reduction in $100 \%$ loans, credit was still amply available.

Figure 5 gives the distributions of the sample with ratios of loan size to income between 1.5 and 3.5 for single earner households in 1988-91 (top half) and 1995-98 (bottom half). The distributions for high and low house price areas are similar. As can be seen, the distribution falls off sharply after 3.0 in the first period but remains high until 3.25 in the second. It appears that lending standards were loosened between the two periods. Figure 6 gives the distributions for the loan-to-income ratio between 1.5 and 3.5 for multiple earner households in 1988-91 (top half) and 1995-98 (bottom half). In both periods the distribution drops off abruptly at 2.5, although significant numbers of borrowers obtain ratios up to 3.0 and some have ratios far above 3.0.

The "certainly unconstrained" borrowers in our sample are defined as those with LTVs below 0.89 and acceptable loan-to-income ratios. Based upon the above analysis, different loan-to-income constraints were applied for single and multiple earner households. In 1988-91 we restrict the sample to loan-to-income ratios below 2.75 (single earners) and 2.4 (multiple earners). In 1995-98 we increase the limit for single earners to 2.9 , but maintain the 2.4 for multiple earners.

Table 2 presents summary data on our samples and how they have been produced. For each of the two house price groups for the two time periods we report both the number of loans we define as certainly unconstrained and the additional number we estimate to be unconstrained. As can be seen, we drop roughly 45 percent of the sample as we move from the logit estimation to the LTV estimation. For the unconstrained borrowers we list the percent (1) with loans above the $£ 30,000$ ceiling, (2) made to previous owners, and (3) made to multiple-earner households, as well as the percentage distribution by age class.

Not surprisingly, the percentage of loans exceeding the $£ 30,000$ ceiling is greater in high than low price areas and in 1995-98 (especially in low price areas) than in 1988-91. The age distribution of borrowers is similar in high and low price areas, but shifts significantly over time with the share of loans to under age 25 borrowers falling and that to ages 35-44 rising between 1988-91 and 1995-98. In both low and high 
house price regions, the share of loans to under age 25 borrowers was 12 percent in 1988-91. By 1995-98 this share was only nine (low price) and five (high price) percent. This shift at least partially reflects the ageing of the baby-boomers. The percentage of loans to previous owners in low price areas fell by five percentage points, while that in high price areas rose by four percentage points. The latter is consistent with the sharp drop in loans to those under age 25.

\section{Estimation}

$1988-91$

Table 3 reports the fit and the estimates of the logit predicting whether a borrower's loan is above or below the $£ 30,000$ limit. As can be seen, 78 and 82 percent of the sample, respectively, are predicted correctly in the low and high price areas. The distributions of the predicted probability of being over the ceiling and of the associated tax penalty variable are shown in Figure 7. The predicted probability distribution is flat through about 0.7 and then rises shapely. The rise reflects the high level of nominal house prices in the Southeast regions. The variation in the predicted tax penalty variable is large. While the variable is less than 0.03 for over two-thirds of the sample, it ranges from 0.045 to 0.06 for a quarter of the sample.

Table 4 reports the regressions of $\operatorname{lnLTV}$. The adjusted R2 is 0.29 . The key coefficient is, of course, that on the tax penalty variable, T_above. This coefficient is -6.4 with a t-ratio of 29 . For high tax rate (40\%) households with a loan over $£ 30,000$, and thus paying a tax penalty, $\operatorname{lnLTV}$ is reduced by $-6.4(.12)(.4)$ $=-0.294$. For low tax rate $(25 \%)$ households, the reduction is $-6.4(.12)(.25)=-0.192$. Assuming an LTV of 0.85 in the absence of the penalty, the LTV would be 0.63 to 0.70 with the penalty. If the LTV were 0.65 in the absence of the penalty, the LTV would be 0.48 to 0.54 with the penalty. That is, leverage would be reduced by 17 (low tax bracket borrowers) to 26 (high tax bracket borrowers) percent.

The elasticities of LTV with respect to primary income and secondary income (income is measured in thousands), respectively, are 0.275 and 0.068 . Higher income households demand larger houses and 
choose to finance them with relatively greater leverage. ${ }^{7}$ The lower leverage elasticity with respect to second incomes likely reflects the ability of households with second incomes to obtain down payment support from two families rather than one (we do not know if the individuals in the household are married). Previous ownership also reduces leverage, although much less for younger households. For households over age 34, the reduction in $\operatorname{lnLTV}$ is 0.28 . For under age 25 households, the reduction is 0.09 .

Table 5 reports some calculations indicating the predicted variation in LTVs across three age groups ( 25 to 34,45 to 54 , and 55 plus) with average single incomes for their age class, with and without a secondary earner with average income, and separately for first-time and previous owners. The calculations are for the dropped year (1991) and region (London) and assume no debt tax penalty. The first two rows give background data on mean incomes of first and second earners for the age groups. The next three (numbered) rows give the log of these mean incomes and mean LTVs. Incomes rise from ages 25-34 to ages 45-54 and then decline for those over age 55.

LTVs decline sharply with age, 30 to 35 percentage points as age increases from 25-34 to over 55 . This is the type of decline commonly seen in developed economies, but note that this decline is for new purchases, not for homeowners generally. The predicted LTVs based on the mean income levels are four (over age 55) to ten (25 to 34) percentage points higher for multiple earner households than for single earner households. Finally, the LTV is about 10 percentage points lower for previous owners.

1995-98

The basic logits and lnLTV results are in Tables 6 and 7. Whether a borrower's loan is above or below the $£ 30,000$ ceiling is correctly predicted by the logit 83 to 86 percent of the time. Figures 8 and 9 , respectively, plot the distributions of the predicted probability of being over the ceiling and of the associated tax penalty variables $T_{-}$above and $T_{-}$below. Owing to the rise in nominal house prices, the probability distribution is now strongly skewed to the right. Half of the sample has a probability greater than 0.8 . The

\footnotetext{
${ }^{7}$ On the other hand, the existence of a second earner in the household reduces leverage (lnLTV is lowered by 0.48). The level of second income at which leverage is unaffected is obtained by solving $0.48=$ $\ln (\mathrm{INCL}) * 0.068$. The solution is $£ 1095$; for second incomes below this level, leverage declines.
} 
tax penalty variables generally have lower values because the level of interest rates declined from 0.12 to 0.07. The right skewness of the probability of being over the ceiling results in a right skewness in T_above and a left skewness in T-below.

The adjusted R2 for the $\operatorname{lnLTV}$ regressions is 0.31 . The previous owner results are similar to those for 1988-91, but the income variables have considerably smaller effects and age coefficients are smaller. This is illustrated by the calculations in Table 8, which assume no penalty and are based on London and 1998. The simulated declines from age 25-34 to 55+ are 23 percentage points for previous owners and 17 percentage points for nonowners, 10 to 15 points less than those in Table 5.

But the actual decline from age 25-34 to $55+$ in the $1995-98$ data was 0.32 , greater than the 0.20 decline based on the 1988-91 data. This greater decline is due to the more widespread tax penalty on the use of home mortgage debt - a penalty that existed whether one's loan was above or below the $£ 30,000$ ceiling and a larger estimated response to it. The two tax penalty coefficients in the first column of Table 7 are both statistically significant with the expected negative sign. The response to the penalty when above the ceiling, T_above, is more than double that in the $1988-91$ period, -14.1 with t-ratio of 29 , versus -6.4 . The response when below the ceiling is much larger, -62.7 with a t-ratio of 41 .

Because of the multiple tax-penalty coefficients, the interpretation of the tax penalty variables is more complicated. Above the ceiling, the penalty is t, below the ceiling it is $t-0.1$ (both times $i=0.07$ ). For households in the 40 percent tax bracket, the lnLTV response to removal of interest deductibility is either $-62.7(.07)(.3)$ - below the ceiling - or -14.1(.07)(.4) - above the ceiling, i.e., -1.62 or -0.39. For households in the 25 percent tax bracket, the estimated response is either $-62.7(.07)(.15)$ or $-14.1(.07)(.25)$, i.e., -0.66 or -0.25 . That is, the response (reduction in lnLTV) is 2.5 to 4 times as great for those below the ceiling than those above. Given that loans below the ceiling are smaller (a half to a fifth on average), the percentage declines can be achieved with far smaller loan payoffs.

One possible reason for the larger responses to T_above in 1995-98 than in 1988-91 (-14.1 versus -6.4 ) is the decline in importance of under age 35 borrowers in the sample noted in Table 2 (from 54 to 48 percent of the sample in low price areas and from 53 to 42 percent in high price areas). If older households 
with greater wealth are more sensitive to the tax penalty, we would expect the average sample response to increase as the sample ages. To test the hypothesis that older households are more responsive, we run a regression with each tax penalty variable entered both by itself and times a dummy variable equaling one for households over age 34 and zero for younger households. The results are in Table 9. These interaction variables, as well as the tax penalty variables themselves are expected to have negative coefficients. The four coefficients are large, negative, and have t-ratios ranging from 7 to $29 .^{8}$

Table 10 reports the impacts of removing the deductibility of mortgage interest for borrowers under age 35 and 35 and older and with loans above and below $£ 30,000$. The tax variable coefficients and t-ratios are in the first two rows of the table, and row 3 gives the cumulative coefficients ("all" for under age 35 and the sum of the "all" and "over 34" coefficients for over age 34). The first two columns are for loans over $£ 30,000$ and the third and fourth for under $£ 30,000$. Rows 4-7 report the distribution of households and average loan amounts for these household groups separately by low (largely 25 percent) and high (40 percent) tax brackets. Note that high tax bracket households are disproportionately older - they are almost twice as likely to be over age 34 , while low tax bracket households are more likely to be under age 35 - and that the average loan size of high tax bracket households with loans over $£ 30,000$ is nearly twice that of low tax bracket households. Because high tax bracket and older households respond more than low tax bracket and younger households, this increases the aggregate response to removal of deductibility.

The impacts of removing deductibility are computed in two ways. First, we shift the probability of being over the $£ 30,000$ ceiling from zero to one, i.e., we use the coefficients from the first two columns. Second, we shift the probability of being under the ceiling from zero to one, using the much larger coefficients from the second two columns. The percentage reduction in leverage from removal of deductibility is $\left(1-\mathrm{e}^{\mathrm{pen}}\right) * 100$, where pen is the product of the tax variable coefficient, the interest rate $(0.07)$, and either the tax rate (loans over $£ 30,000$ ) or the tax rate less 0.1 (loans below $£ 30,000$ ). For those with loans above the $£ 30,000$ ceiling the reduction ranges from 19 to 29 percent for those under age 35 and from

\footnotetext{
${ }^{8}$ The age interaction tax penalty variable was tested with the 1988-91 subsample, but its coefficient was insignificantly different from zero. For 1995-98, an under age 25 interaction was tested in addition to the over age 34 interaction. The under age 25 coefficients were positive, as expected, but small.
} 
23 to 34 percent for those 35 and older. These percentage declines are, on average, about the same as the 17 to 26 percent declines based on the 1988-91 sample, even though the level of interest rates was only 7 percent in 1995-98 versus the 12 percent in 1988-91 and thus the tax penalty was less.

The declines in leverage for those with loans less than the ceiling (columns three and four) are much larger, 40 to 65 percent for young households and 53 to 78 for older households. Given that we are dealing here with smaller volume loans, the percentage declines can be achieved with smaller loan payoffs. The larger responses are because the greater estimated response to the tax penalty outweighs the smaller penalty (the tax rate less 0.1, rather than the full tax rate). Of course the fact that these loans are small means that even these large responses are not very important to the aggregate response. In fact, the weighted average LTV response for the eight household groups is a 30 percent decline.

How much government tax revenue would be gained by elimination of tax deductibility depends on who (high or low tax rate payers) is repaying the debt, as well as how much is repaid. Say that the "static" (no behavioral responses) estimate of the revenue lost owing to deductibility is $£ 10$ billion and that mortgage debt declines by 30 percent in response to the removal of deductibility. The government revenue pickup will be significantly less than $£ 7$ billion because high tax bracket households would repay relatively more debt than low tax bracket households. Not only do higher tax bracket households respond about twice as much because their tax penalty is greater, but higher tax bracket households have loans that are almost twice as large. The response of older households with the same tax penalty is about 20 percent greater than that of younger households, probably owing to their having greater wealth relative to income.

\section{Summary and Conclusion}

We analyze over 117,000 UK loan originations split about equally between the 1988-91 and 1995-98 periods. Because the tax penalty to using debt varied during these periods with whether a borrower had a loan above or below $£ 30,000$, we first estimate logit equations explaining whether the loan exceeded $£ 30,000$ and then use the predicted probability of the borrower's loan exceeding this amount in computing our two tax penalty variables. The variables represent the penalty per unit of debt if the loan is above $£ 30,000-$ the 
product of the tax rate and the interest rate - or below - the product of the interest rate and the difference between one's marginal income tax rate and the rate at which mortgage interest is deductible.

We establish a major sensitivity of leverage to the debt tax penalty created for many households (for all during the $1995-98$ period) by the partial deductibility of mortgage interest. This sensitivity exists for both time periods. Based on this, we can infer what the impact of removing the interest deduction would be relative to having the full deduction. Because estimates for the latter period are less sensitive to the accuracy of the logits used in computing the tax penalty variables, we view them as more credible. Our best estimate is that leverage of those with loans over $£ 30,000$ would decline by 19 to 34 percent, the larger percentage applying to older (over age 34) borrowers in the 40 percent tax bracket. For those with smaller loans (under the $£ 30,000$ ceiling), the estimates are far larger - a 40 to 78 percent decline. Because 80 percent of loans are above $£ 30,000$, the aggregate decline would be about 30 percent.

Our analysis is based on new loans for home purchase. Homeowners with existing loans will also pay down their loans. Because these households are older and many will have smaller loans, they are likely to be more sensitive to removal of the mortgage interest deduction (although effective prepayment penalties would make this response less/slower in the UK than in the U.S.). On the other hand, we have excluded 45 percent of new loans on the grounds that the borrowers may have been income or wealth constrained. These borrowers would be less sensitive to the tax penalty than unconstrained borrowers. Overall, our estimates of a reduction in the average UK leverage suggest a smaller - say 25 to 30 percent response than the 40 percent found in earlier studies of Australia and U.S. data.

The tax revenue gained by the government from removal of the home mortgage interest deduction will be less than the product of the average tax rate at which interest is deducted and the amount of debt not repaid for a variety of reasons. First, the average tax rate will decline because high tax bracket households will repay disproportionately larger fractions of their debt owing to their having a larger tax penalty and having greater relative wealth to repay debt. Second, removal of deductibility will lower the volume of single-family housing to be financed by raising the weighted average user cost of capital (WACC), although the debt response mitigates the rise in WACC, our concluding topic. 
Initially assume full deductibility, a mortgage rate of 8 percent and an after-tax risk premium of one percent. Consider two households, one in the 40 percent tax bracket and the other in the 25 percent bracket. Their WACCs $-(1-t) 8+1-$ are, respectively, 5.8 and 7 percent. Without deductibility, their WACCs rise to (1-t) $8+1+$ LTVt8. Table 11 gives the WACC for these households assuming alternative initial LTVs -0.9 and 0.7 - and alternative percentage declines in leverage in response to the removal of interest deductibility 20,30 and 40.

Of course, with no decline in LTV, the increases are the largest, being greater the higher the initial LTV. The percentage decline in LTV acts as a direct offset to the percentage increase in WACC - if LTV declines by 30 percent, the increase in the WACC is only 70 percent of what it otherwise would have been. Consider the 0.9 LTV. With no change in leverage, removal of the deduction increases the WACC by 1.8 to 2.9 percentage points or 26 to 50 percent (the larger numbers for households in the 40 percent tax bracket). With a 30 percent decline in leverage, the increase in the WACC is reduced by 30 percent or a half to a full percentage point.

Changes in household leverage would significantly offset the negative impact of the removal of interest deductibility on house prices, housing consumption and home ownership. To illustrate, consider the extreme case where all of the increase in WACC causes a reduction in housing consumption. In the appendix we estimate that the elasticity of housing demand with respect to the WACC is -0.25 to -0.4 . Thus if the WACC rises by 30 percent, the decline in housing consumption would be 7.5 to 12 percent. On the other hand, if leverage adjustments offset half of the rise in WACC, the decline in consumption would be only 4 to 6 percent.

At the other extreme, the rise in WACC could simply lower real house prices. In this case, a 30 percent rise in the WACC translates directly into a 30 percent price decline. Thus a halving of the increase in WACC would half the price decline. A mixture of consumption and price declines would be expected, but the declines would, according to our estimates, by reduced by about a third by the leverage response. 


\section{Appendix: Determining Credit Constrained Borrowers}

The LTV functions were estimated using a five-step procedure applied separately to each time period. The last two steps were discussed in detail in the text and so it is the first three steps, relating to the treatment of rationed borrowers, that is our focus here. Before detailing each step, it is worth summarizing the overall strategy. The goal is to develop a methodology for identifying unrationed borrowers. We first specified a subsample of borrowers who we believe to be clearly unrationed given their loan-to-value and loan-to-income ratios. We then estimated a housing demand function for this group of borrowers and used this function to estimate the demand for each household in the rest of the sample and compared it to their actual demand. If actual demand equaled or exceeded predicted demand, the household was added to our unrationed sample, on which our final LTV function was estimated. Sample selection effects were captured using the Heckman estimation procedure. This method translates into a five step procedure.

\section{Step 1: Estimate $\psi_{b t}$}

$\psi_{b t}$ is the predicted probability that the borrower's loan will be less than or equal to the $£ 30,000$ ceiling on tax deductibility. This probability is needed in the construction of the user cost of capital variable in the demand regressions estimated in step 2.

$\psi_{b t}$ was estimated by running logits (dependent variable $=$ whether or not the borrowers loan exceeded the $£ 30,000$ limit) on a subsample of clearly unrationed borrowers, selected as those borrowers in the 1988-91 (1995-98) period with a loan to value ratio less than or equal to $0.89(0.89)$ and either a loan to primary earner income ratio less than or equal to 2.75 (2.9) or a loan to total income ratio less than or equal to 2.4 (2.4). This resulted in a basic sample of unrationed borrowers in 1988-91 (1995-98) of 44,506 $(38,836)$. Separate logits were run for low and high house price regions.

\section{Step 2: Estimate unconstrained housing consumption}

The housing demand equation followed Hendershott and Pryce (2002),

$$
\ln H C_{b}=\beta_{0}+\beta_{1} \ln M C H_{b}+\beta_{2} \ln Y_{b}+\beta_{3} A G E_{b}+\beta_{4} A G E_{b}^{2},
$$


where $\ln H C$ is the $\log$ of housing consumption, $\ln M C H$ is the $\log$ of the marginal cost of housing, $\ln Y_{b}$ is the $\log$ of total income, $A G E$ is the age of the main borrower, $\ln Y_{b}$ is the $\log$ of total income, the $\beta_{i}$ are the estimated coefficients, and the subscript $b$ refers to household $b$. We adopt Goodman and Kawai's (1982) method for calculating $H C$, defining it as the actual household house price (times a constant imputed rental rate that is absorbed in the constant term when logs are taken) divided by the constant-quality price. The latter is estimated using hedonic regressions of price on housing attributes and quarter dummies, run separately for each of the ten regions and each year.

The marginal cost of housing was calculated as, $M C H_{t}=U C C_{t}\left(\hat{P}_{r t} / \mathrm{RPI}_{\mathrm{t}}\right)$, where RPI is monthly retail price index, and $U C C$ is the user cost of capital, defined as the mortgage interest rate $i$, less the tax deductible component $\tau$, plus the rate of depreciation (assumed to be 0.01 for all households), plus property taxes (0.02), and less expected capital gains, $\pi_{r t}^{*}$ :

$$
U C C=\left(1-\tau_{b t}\right) i_{t}+0.03-0.3 \pi_{r t}^{*}
$$

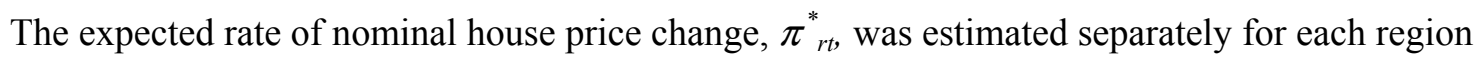
using the backward-looking expectations approach of Ermisch, Findlay and Gibb (1996). That is, $\Delta \hat{P}_{\mathrm{rt}}$ was regressed on $\Delta \hat{P}_{\mathrm{rt}-1}$ from 1979 quarter one through to 1998 quarter four, where $\Delta \hat{P}_{r t}$ is the four quarter difference in the price index, $\Delta \hat{P}_{r t}=\hat{P}_{r t}-\hat{P}_{r t-4}$, and the estimated parameters used to forecast expected house price inflation for each region in each quarter).

The constant quality price house price index used for these calculations was constructed using the selling price and dwelling characteristics information in the CML Survey of Mortgage Lenders data. For each of the ten regions region, separate regressions were run on selling price for each year of the data since 1979 (explanatory variables $=$ number of rooms, number of rooms squared, age of dwelling dummies, type of dwelling dummies, room-type interactive terms, and quarterly dummies on selling price) thus allowing marginal valuations of characteristics to change from year to year. These regressions (200 in total) had an 
average adjusted $\mathrm{R}^{2}$ of 0.48 based on samples of around 1,500 depending on the region and the time period. We then predicted value of a constant quality dwelling (a five bedroom, semi-detached, post war dwelling) for each region in each quarter $=\hat{P}_{r t}$.

A weight of 0.3 was applied to $\pi_{r t}^{*}$ following Ermisch, Findlay and Gibb (1996). The tax deductible component $\tau$, was computed by multiplying the borrower's marginal income tax rate $T_{b}$ by $\psi_{b t}$, the predicted probability that the borrower's loan would be less than or equal to the $£ 30,000$ ceiling on tax deductibility (computed in Step 1). As in the final LTV regressions, the household tax rate used in this estimation, $T_{b}$, was computed as the tax rate on the first pound of housing purchased by adding an estimate of the income the household would have earned on the equity invested in purchasing the house to reported income.

The housing demand regression was run on the subsample of easily identifiable unrationed borrowers and the estimated parameters (listed in Table A) were used to predict unrationed housing demand. Missing values reduced the basic unrationed sample in 1988-91 (1995-98) by 3,065 (7,933) observations to $41,441(30,903)$ cases. The estimated income elasticity is about 0.6 and the price elasticity is $-0.25(1995$ 98) to $-0.4(1988-91)$.

\section{Step 3: Compare actual and predicted demands for households in the remaining sample}

If actual demand (as recorded in the data) equals or exceeds predicted demand (the antilog of the predicted values from the demand regressions in Table A), the household was added to our unrationed sample.

\section{Step 4: Predict the probability of exceeding the ceiling}

The logits were re-run on the enlarged sample and the estimated parameters used to predict the probability of exceeding the ceiling. This probability was used to construct the tax penalty variable in the LTV regression.

\section{Step 5: Run the LTV regression}

Finally, the LTV regression was run on the expanded unconstrained sample using the Heckman procedure to account for selection effects. 


\section{References}

Capozza, Dennis, Richard Green and Patric H. Hendershott. 1996. "Taxes, Home Mortgage Borrowing and Residential Land Prices," in Aaron and Gale, (eds), Fundamental Tax Reform, Brookings Institute, Washington, DC, 171-210.

Devereux, Michael P. and Gauthier Lanot. 2001. "Measuring tax incidence: an application to mortgage provision in the UK," working paper, August.

Dunsky, Robert M. and James R. Follain. 2000. "Tax-Induced Portfolio Reshuffling: The Case of the Mortgage Interest Deduction," Real Estate Economics, 28, 683-718.

Ermisch, John, Findlay, J., and Kenneth Gibb. 1996. "The Price Elasticity of Housing Demand in Britain: Issues of Sample Selection," Journal of Housing Economics, 5, 64-86.

Follain, James R. and Robert M. Dunsky. 1997. "The Demand for Mortgage Debt and the Income Tax," Journal of Housing Research, 8 155-199.

Follain, James R., and David C. Ling. 1991. "The Federal Tax Subsidy to Housing and the Reduced Value of the Mortgage Interest Deduction," National Tax Journal. 44, 253-266.

Follain, James R. and Lisa S. Melamed. 1998. "The False Messiah of Tax Policy: What Elimination of the Home Mortgage Interest Deduction Promises and a Careful Look at What It Delivers," Journal of Housing Research, 9, 179-199.

Greene, W. H. 1993. Econometric Analysis, Macmillan: New York.

Goodman, Allan and M. Kawai. 1982. "Permanent Income, Hedonic Prices, and Demand for Housing: New Evidence," Journal of Urban Economics, 12, 214-237.

Haurin, Donald R., Toby Parcel, and R. Jean Haurin. 2002. "The Impact of Homeownership on Child Outcomes," Real Estate Economics, 30.

Hendershott, Patric H., James R. Follain, and David C. Ling. 1987. "Effects on Real Estate," in Pechman (ed.), Tax Reform and the U.S. Economy, The Brookings Institution, Washington, D.C., 71-94.

Hendershott, Patric H. and Gwilym Pryce. 2002. "Estimating the Price Elasticity of Demand in the UK: Incorporating the Impact of Mortgage Interest Tax Relief and Credit Rationing Sample Selection Effects," paper read at the European Real Estate Society Meetings, June 5-7, Glasgow.

Hendershott, Patric H. and Joel Slemrod. 1983. "Taxes and the User Cost of Capital for Owner-Occupied Housing," AREUEA Journal, 11, 375-393.

Hendershott, Patric H. and Thomas Thibodeau. 1990. "The Relationship Between Median and Constant Quality House Prices: Implications for Setting FHA Loan Limits," AREUEA Journal, 18, 323-334.

Hendershott, Patric H. and Michael White. 2000. "The Rise and Fall of Housing's Favored Investment Status," Journal of Housing Research, 11, 257-275.

Hills, J. 1991. Unraveling Housing Finance, Clarendon Press, Oxford. 
Ling, David C. and Gary A. McGill. 1998. "Evidence on the Demand for Mortgage Debt by Owner Occupiers, Journal of Urban Economics, 44, 391-414.

Woodward, Susan E. and John C. Weicher. 1989. "Goring the Wrong Ox: A Defense of the Mortgage Interest Deduction," National Tax Journal, 42, 301-313. 


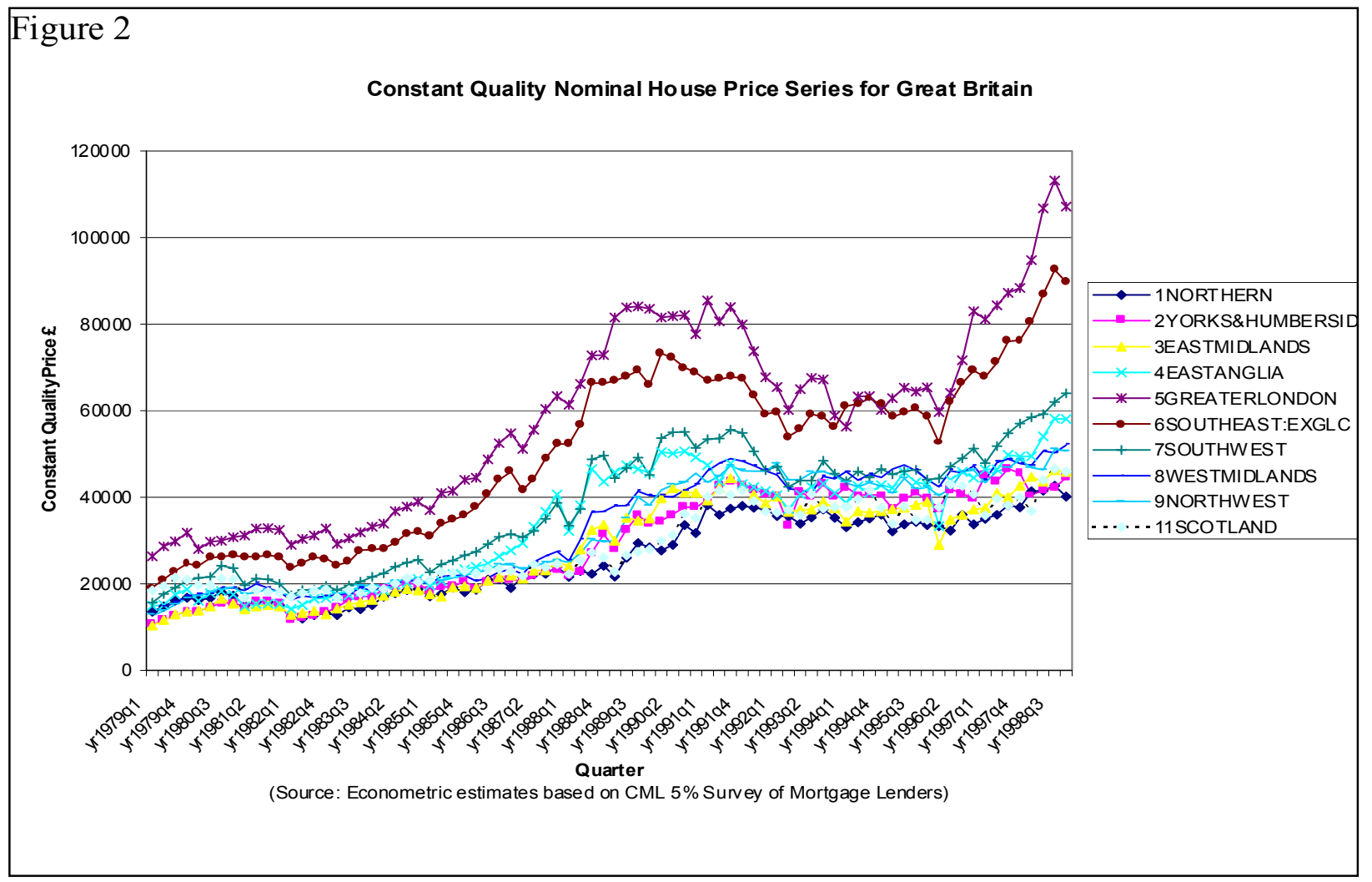

Figure 3 1988-91 Loan to Value Ratio

\section{LTVs between 0 and 1}

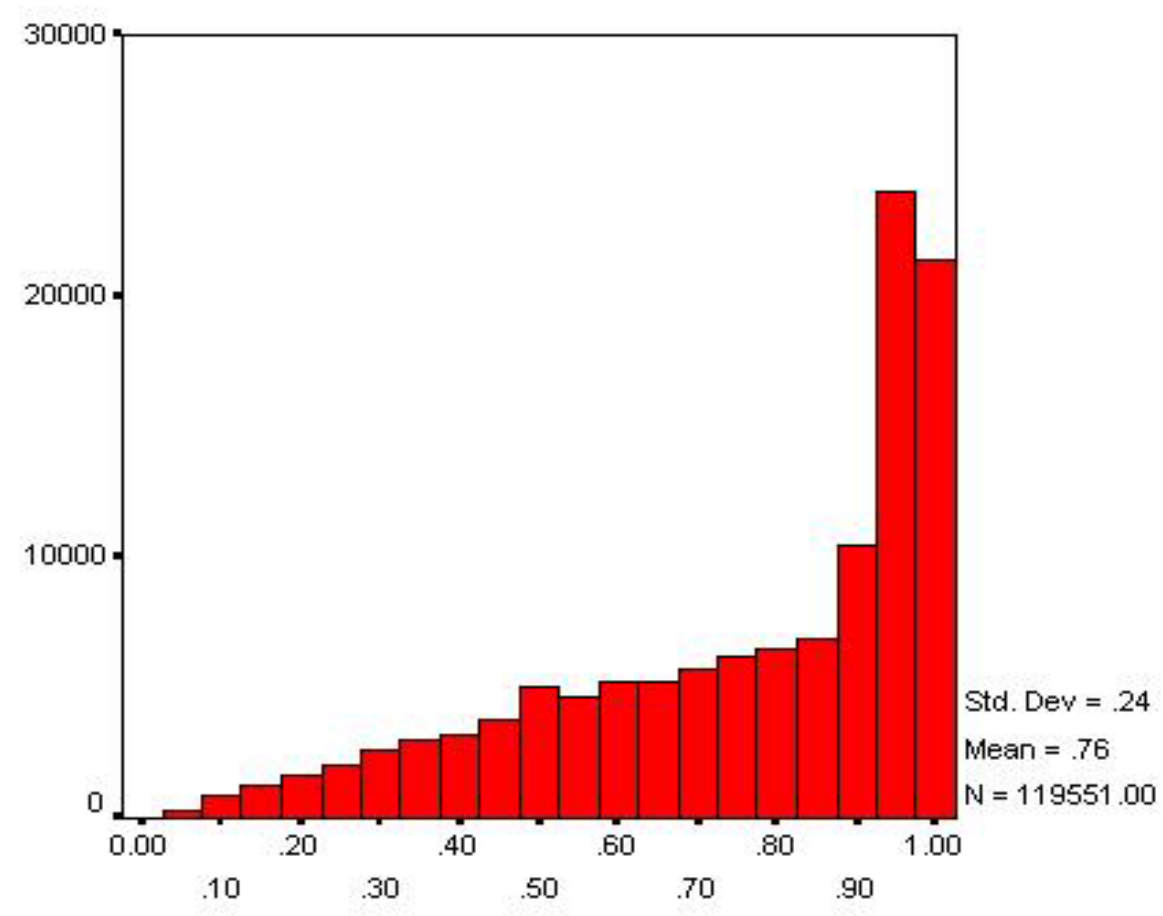




\section{LTVs between 0.8 and 1}

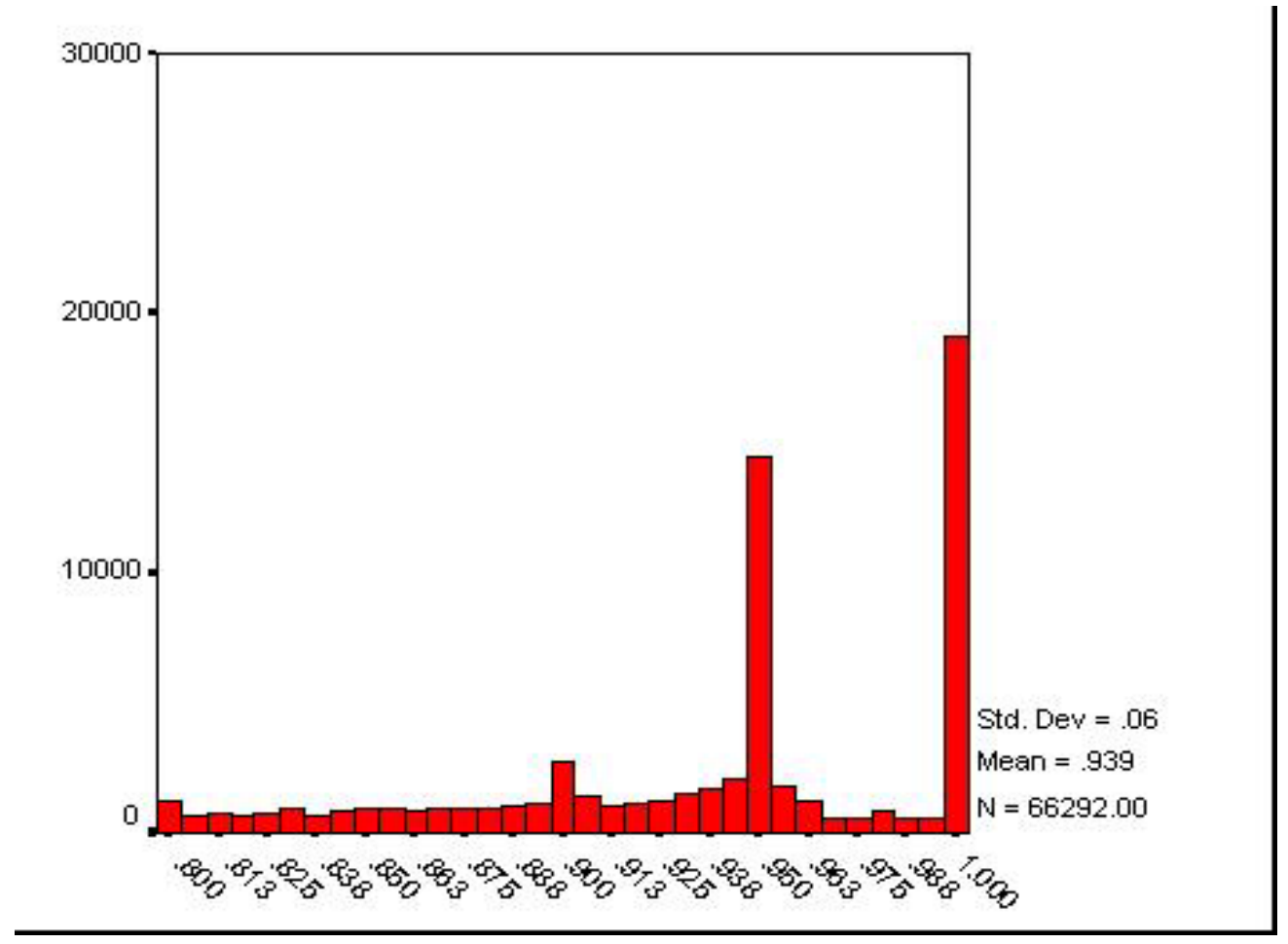

Figure $4 \quad$ 1995-98 Loan to value Ratio

LTVs between 0 and 1

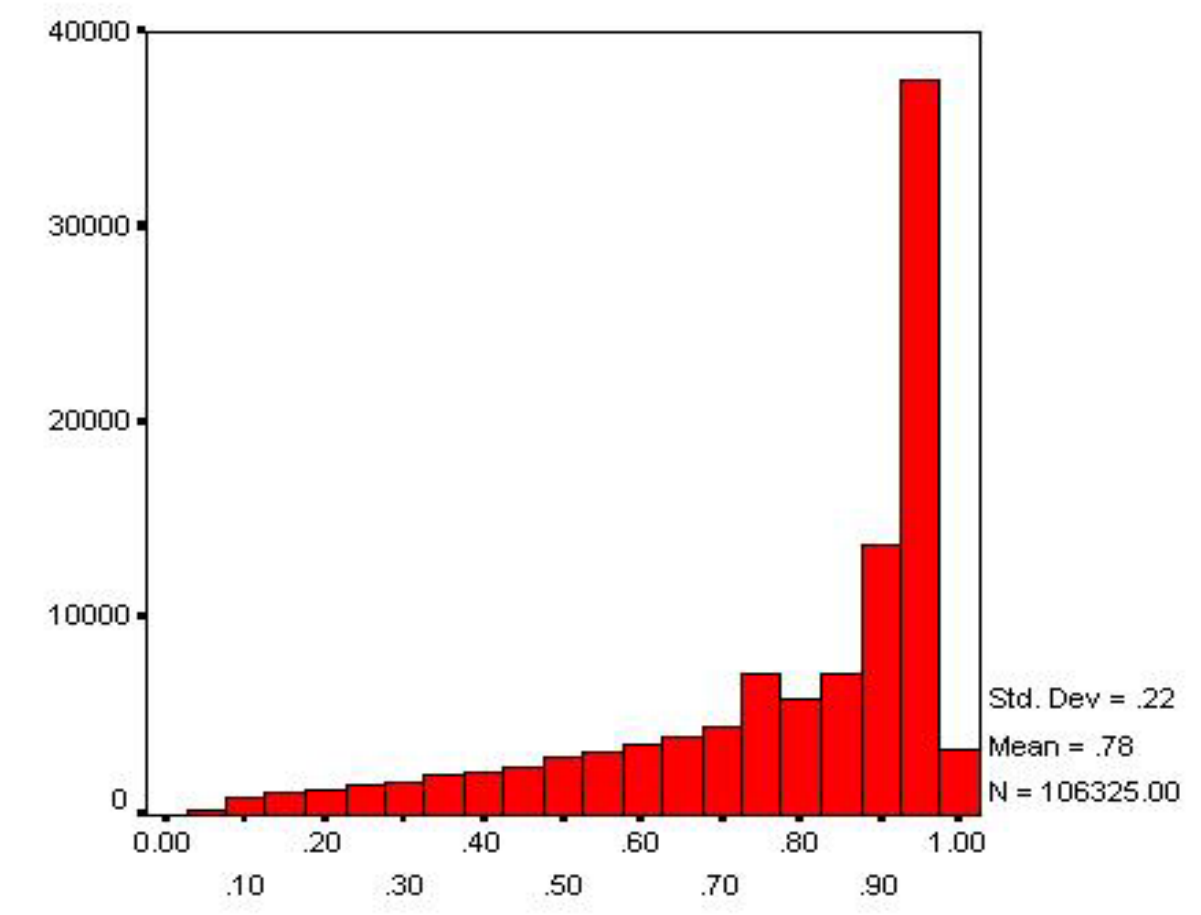




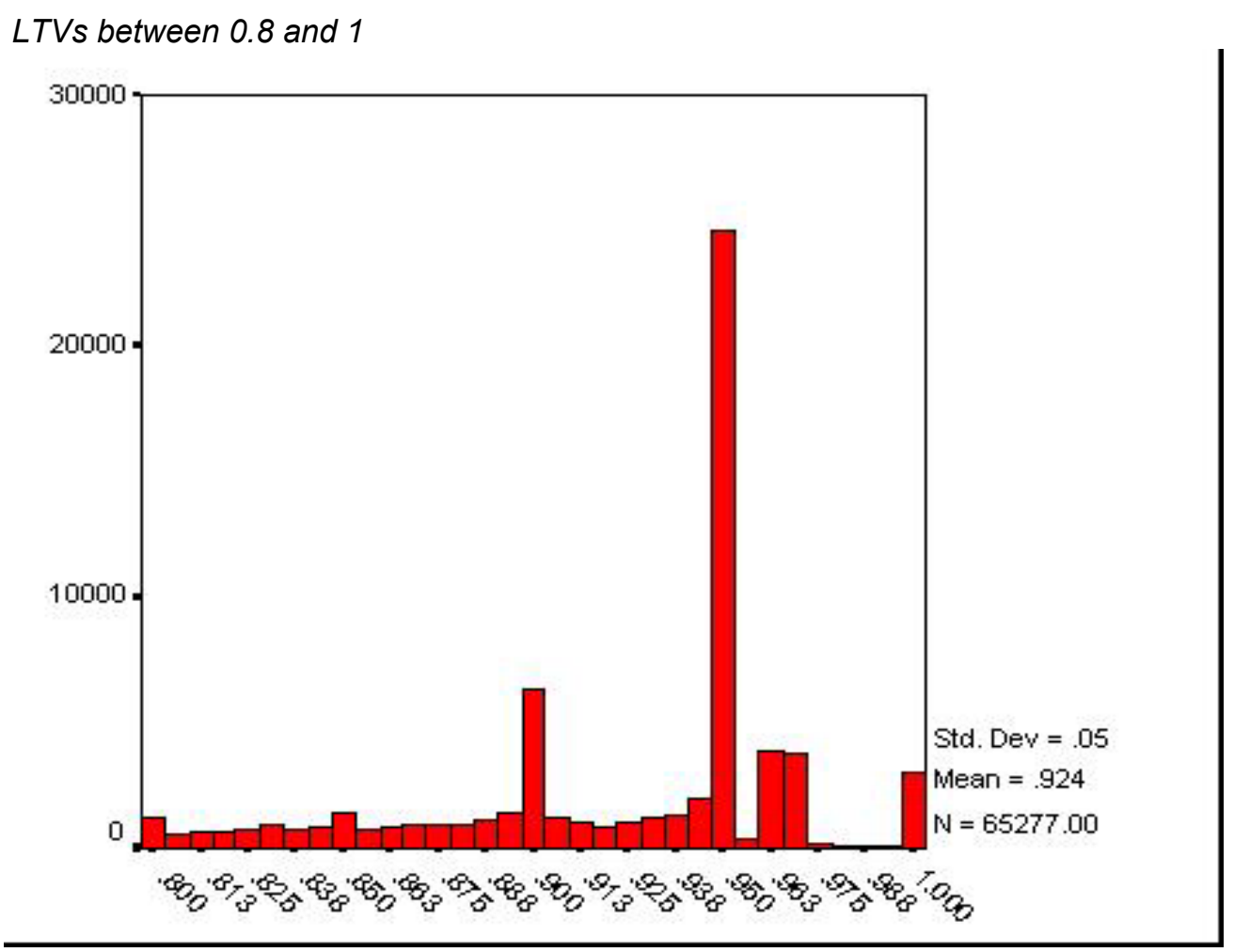

Figure 5 Loan to Income Ratios for Single Earners

$1988-91$

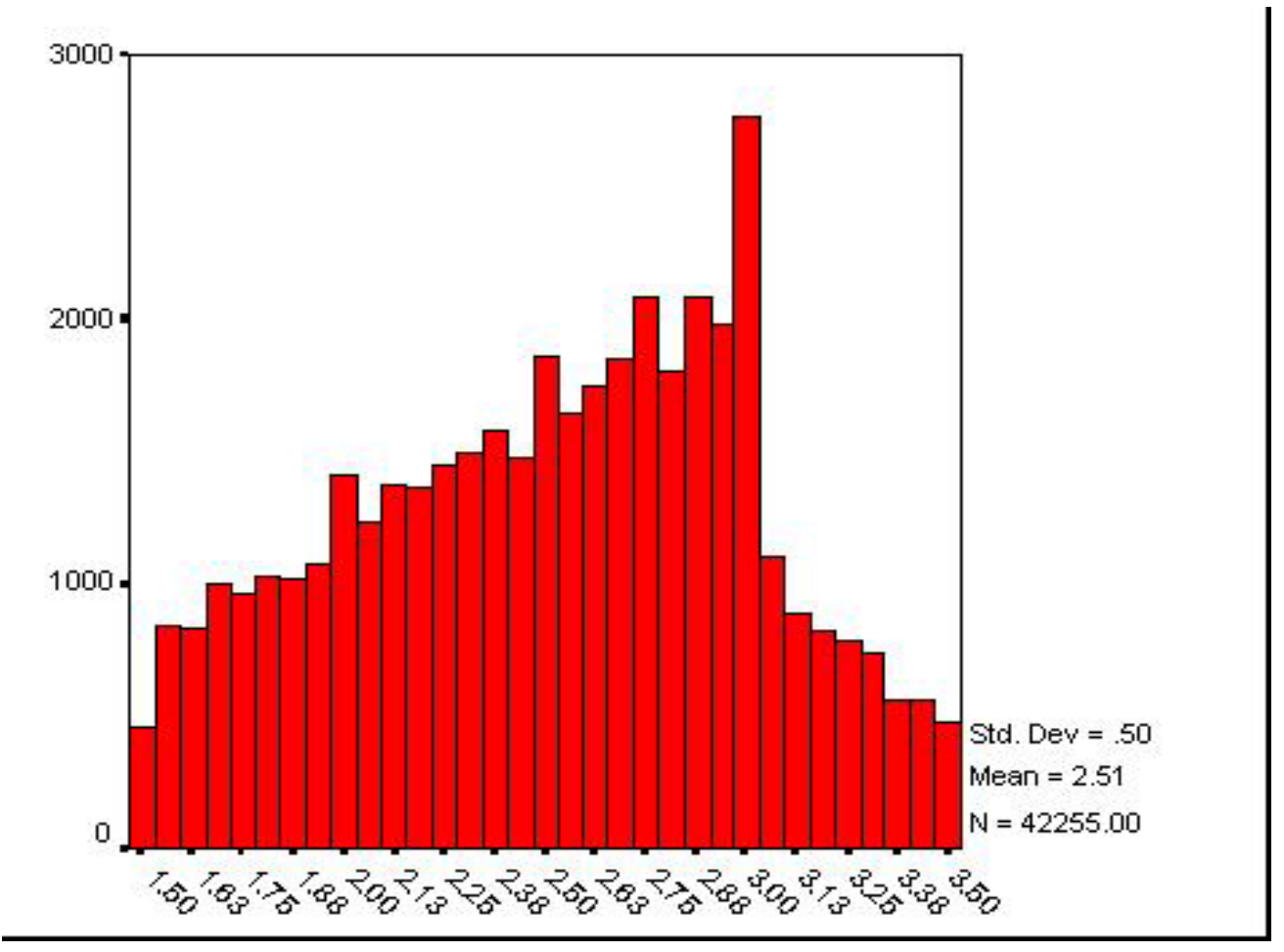




\section{$1995-98$}

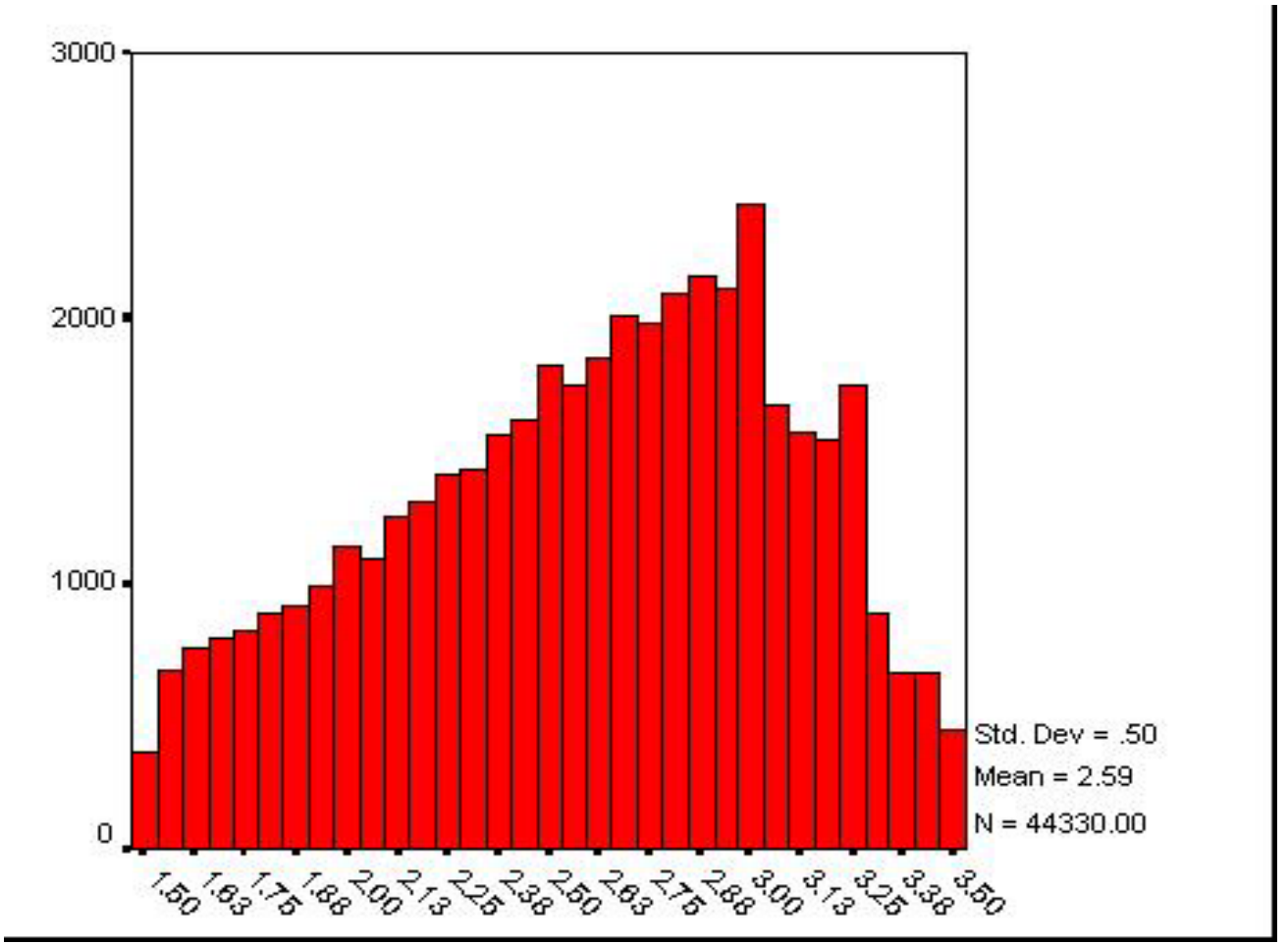

Figure 6 Loan to Income Ratio for Multiple Earners

1988-91

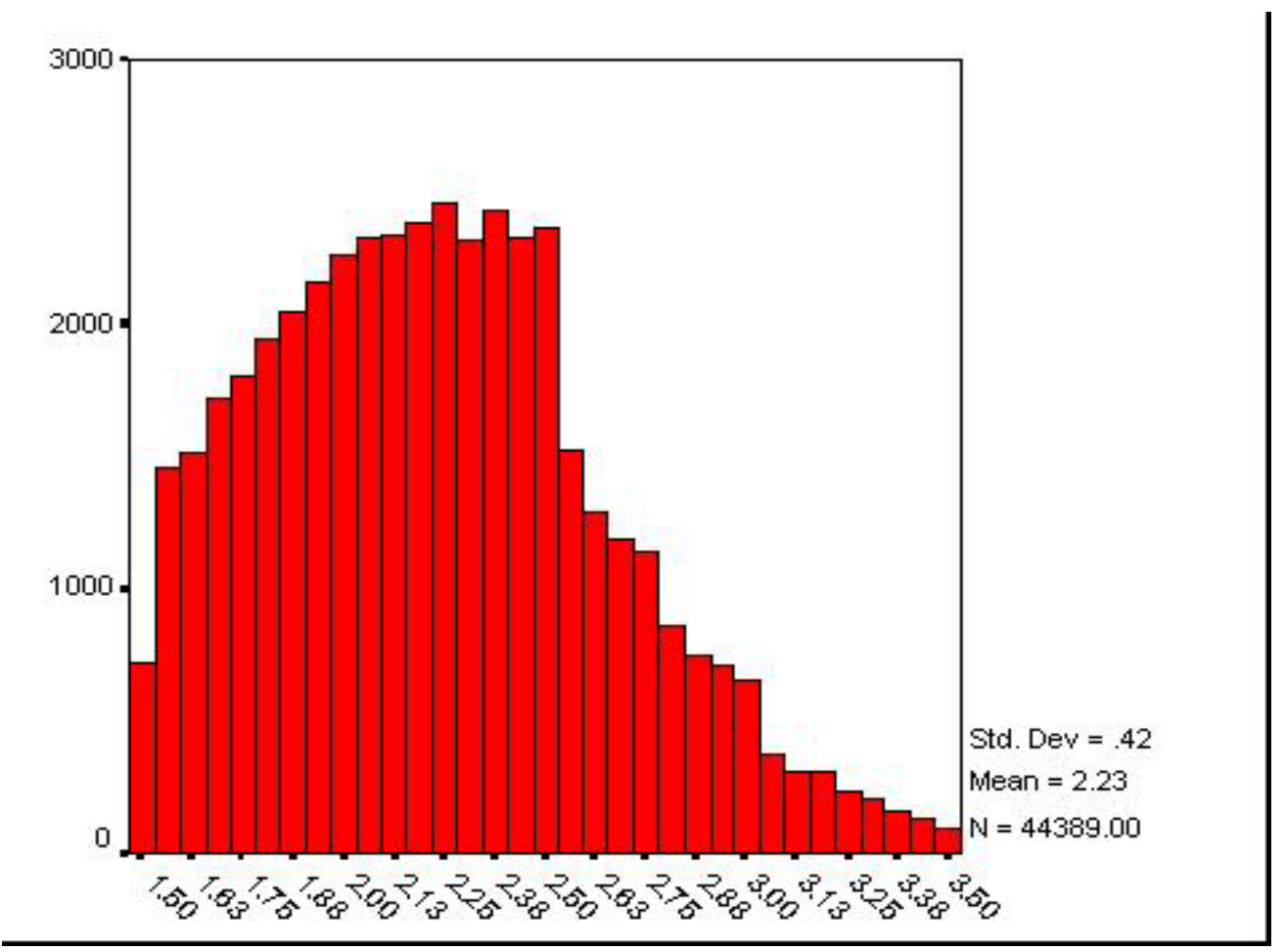


1995-98

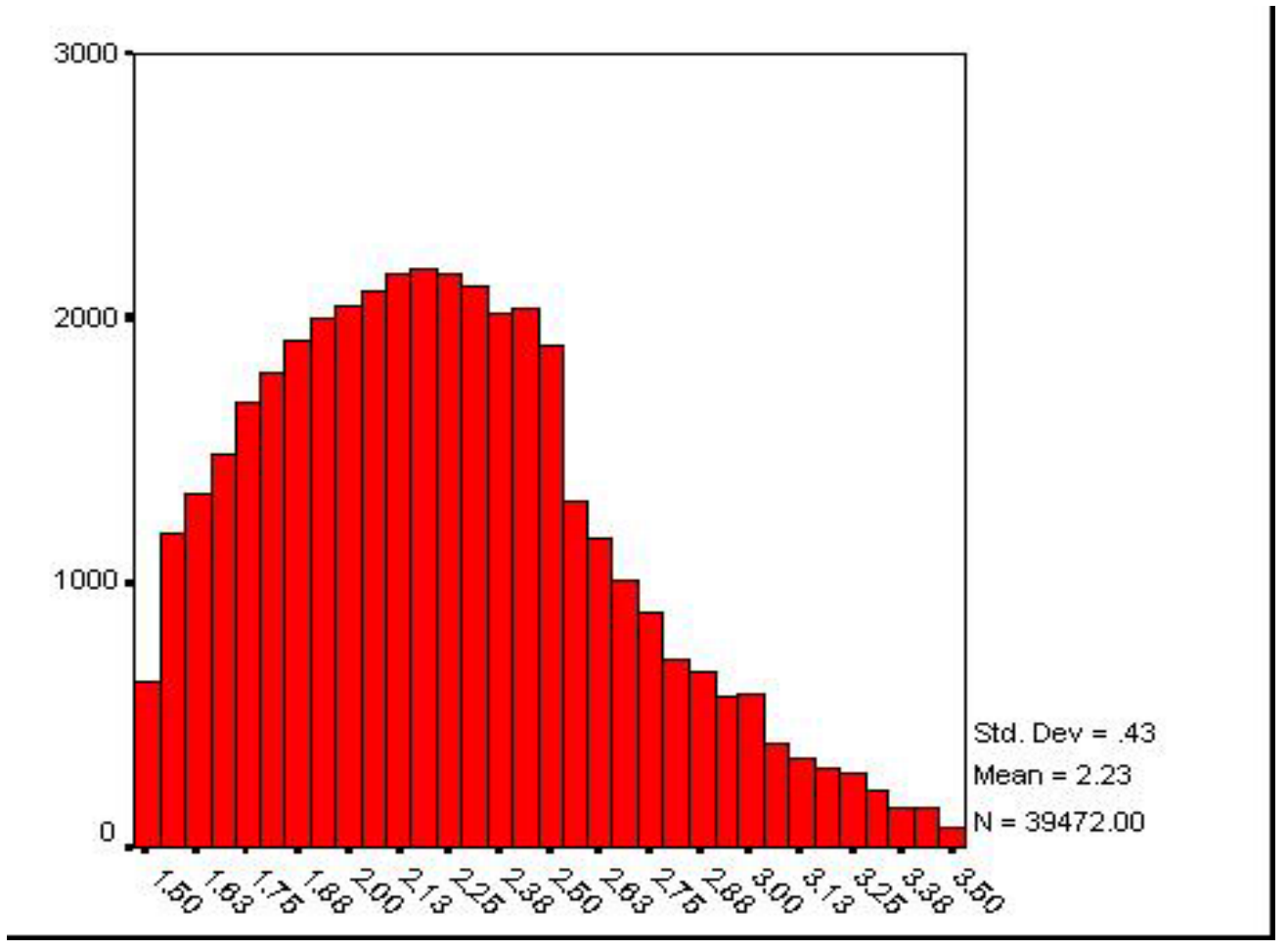

Figure $7 \quad$ 1988-91

Predicted Probability of Being over the Ceiling

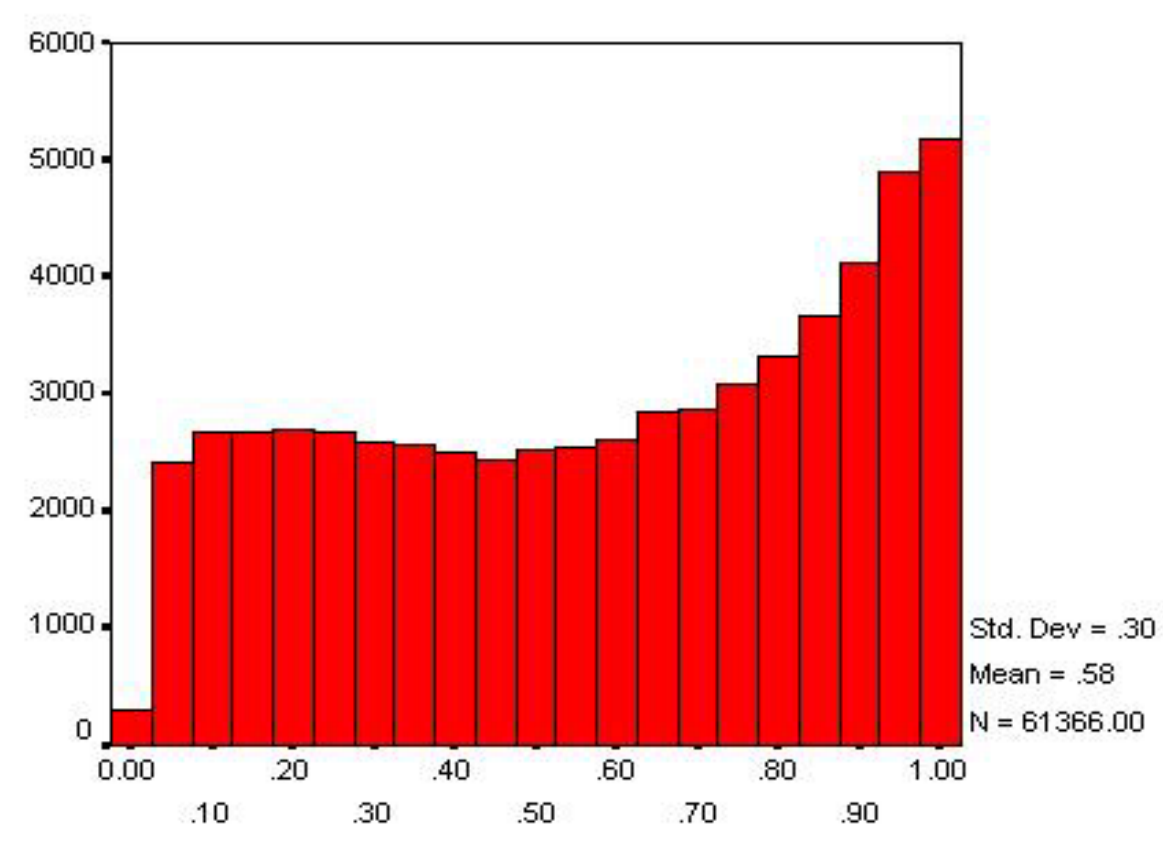

PCEIL 


\section{Distribution of T_Above}

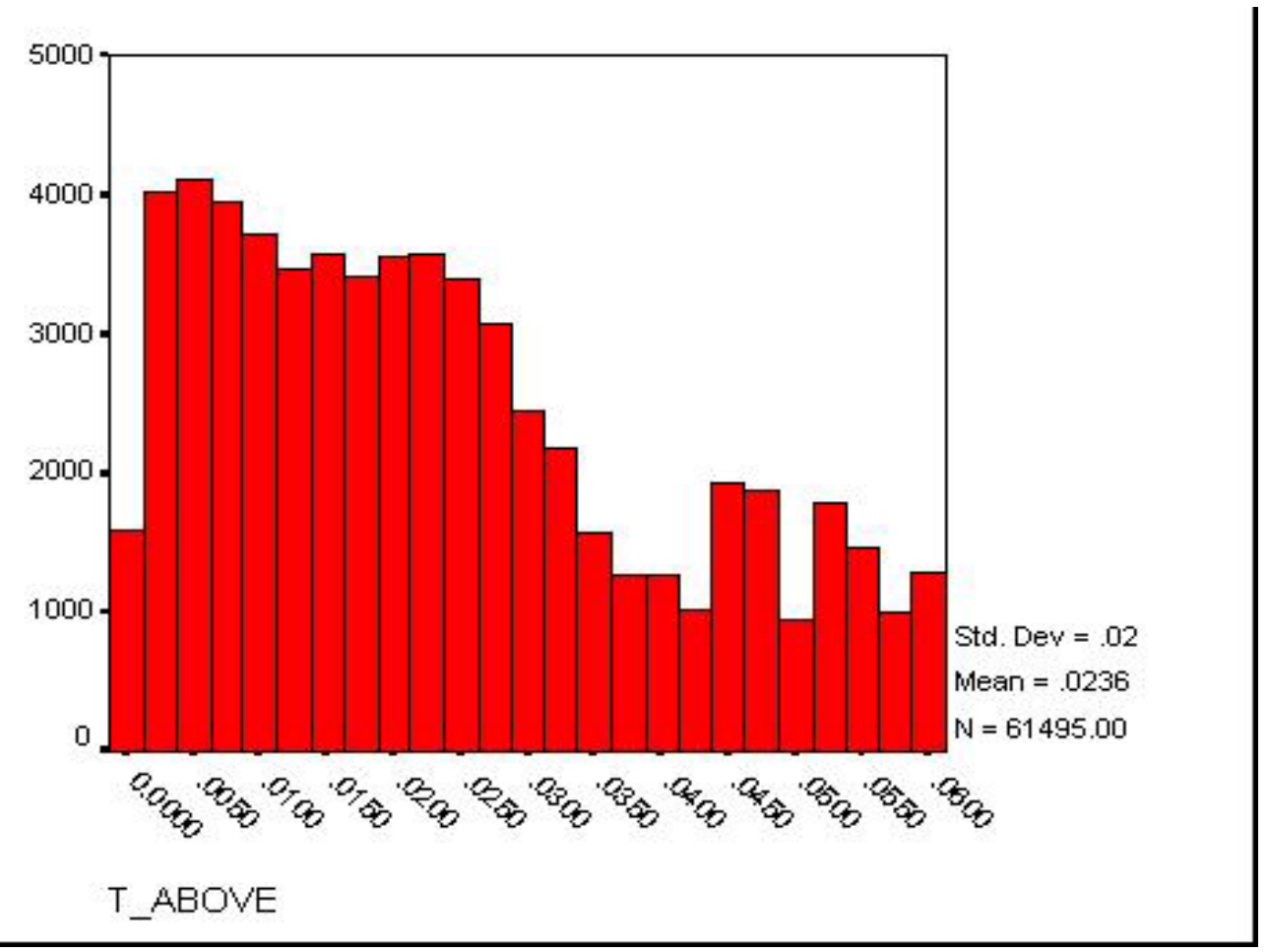

Figure $8 \quad$ 1995-98

\section{Predicted Probability of Being over the Ceiling}

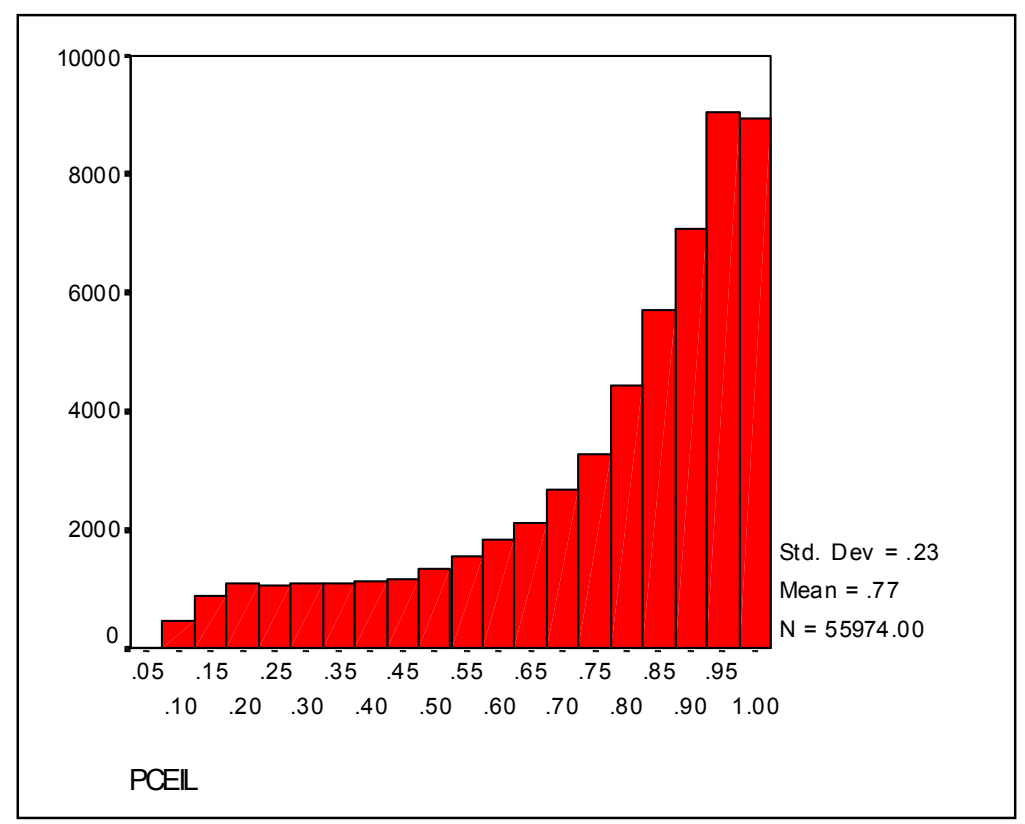


Figure $9 \quad$ 1995-98

\section{Distribution of T_Above}

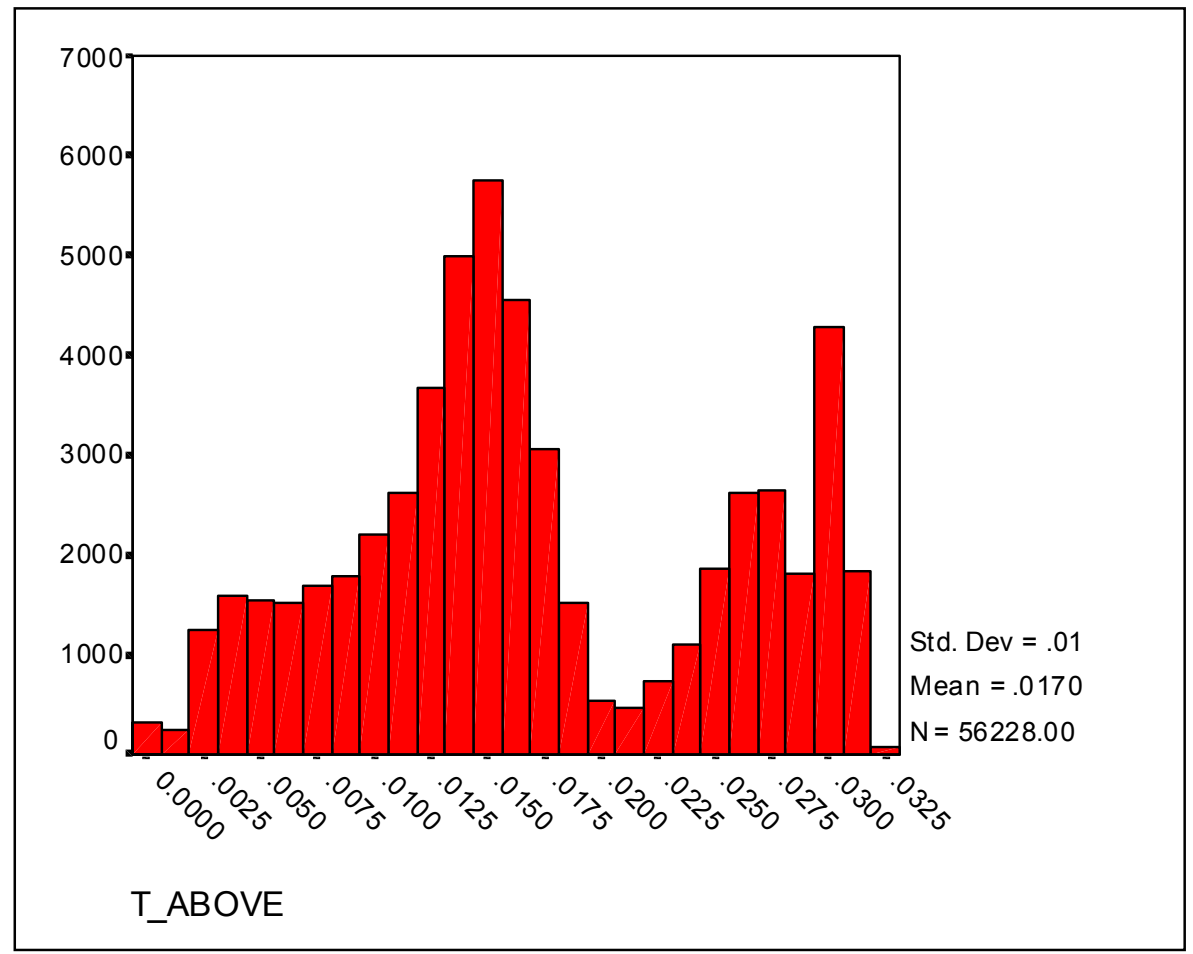

\section{Distribution of T_Below}

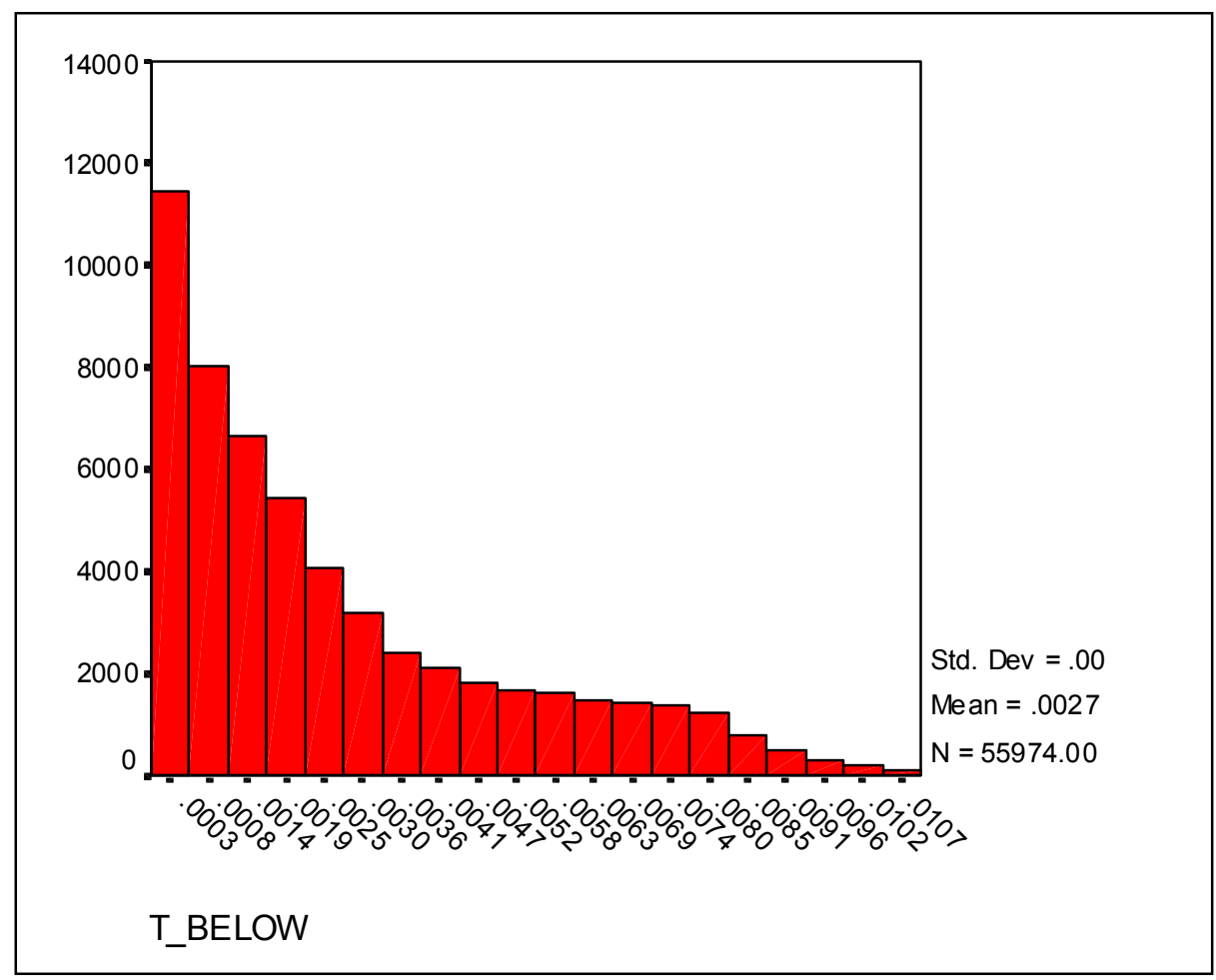


Table 1: Limitations of Mortgage Interest Deductibility

A: Limits on The Amounts Deductible

\begin{tabular}{|l|c|c|c|}
\hline \multicolumn{1}{|c|}{ Year } & Limit $(£)$ & Median House Price $(£)$ & \% of Mortgages above Limit \\
\hline 1974 & 25000 & 10800 & 0 \\
\hline 1983 & 30000 & 29400 & 5.4 \\
\hline $1988-91$ & 30000 & 63000 & 48.4 \\
\hline $1995-98$ & 30000 & 73800 & 67.4 \\
\hline
\end{tabular}

\section{B: Limits on Rate Deductibility}

\begin{tabular}{|l|c|c|c|}
\hline \multicolumn{1}{|c|}{ Year } & Tax Rate & Max Deductible \% & $\begin{array}{c}\% \text { of Mortgages } \\
\text { above Max }\end{array}$ \\
\hline $1988-91$ & 25,40 & 25,40 & ---- \\
\hline $1992-93$ & 25,40 & 25 & 26 \\
\hline 1994 & 25,40 & 20 & 100 \\
\hline $1995-98$ & 25,40 & 10 & 100 \\
\hline 1999 & 23,40 & 0 & 100 \\
\hline
\end{tabular}




\begin{tabular}{|l|c|c|}
\hline Table 2: Descriptive Statistics & & \\
A: 1988-91 & $\begin{array}{c}\text { Low Price } \\
\text { Regions }\end{array}$ & $\begin{array}{c}\text { High Price } \\
\text { Regions }\end{array}$ \\
\hline Total Number of mortgages (cases with missing values excluded) & $\mathbf{6 2 , 5 2 2}$ & $\mathbf{4 9 , 3 4 9}$ \\
Certainly unconstrained & 24,762 & 17,293 \\
Estimated unconstrained & 9,827 & 9,484 \\
& & \\
Total unconstrained (= Certainly + Estimated = logit sample ) & $\mathbf{3 4 , 5 8 9}$ & $\mathbf{2 6 , 7 7 7}$ \\
$\%$ of Total number of mortgages that are unconstrained & 55.32 & 54.26 \\
\hline Characteristics of Unconstrained Borrowers: & 47.08 & \\
$\%$ of Total unconstrained with loans over £30,000 & 70.93 & 71.86 \\
$\%$ of Total unconstrained who are previous owners & 45.70 & 4.23 \\
$\%$ of Total unconstrained who are multiple earners & 12.06 & 12.27 \\
$\%$ of Total unconstrained aged under 25 & 41.91 & 40.71 \\
$\%$ of Total unconstrained aged 25 to 34 & 25.40 & 26.02 \\
$\%$ of Total unconstrained aged 35 to 44 & 12.34 & 12.92 \\
$\%$ of Total unconstrained aged 45 to 54 & 8.01 & 7.79 \\
\hline$\%$ of Total unconstrained aged over 54 & & \\
\hline
\end{tabular}

\begin{tabular}{|l|c|c|}
\hline Table 2: Descriptive Statistics & Low Price \\
B: 1995-98 & $\begin{array}{c}\text { High Price } \\
\text { Regions }\end{array}$ \\
\hline Total Number of mortgages (cases with missing values excluded) & $\mathbf{6 4 , 0 5 8}$ & $\mathbf{3 9 , 8 3 0}$ \\
Certainly unconstrained & 23,175 & 14,277 \\
& & \\
Estimated unconstrained & 14,034 & 4,488 \\
Total unconstrained (= Certainly + Estimated logit sample ) & 37209 & 18765 \\
$\%$ of Total number of mortgages that are unconstrained & 58.09 & 47.11 \\
\hline Characteristics of Unconstrained Borrowers: & & \\
$\%$ of Total unconstrained with loans over £30,000 & 74.44 & 81.20 \\
$\%$ of Total unconstrained who are previous owners & 65.92 & 75.18 \\
$\%$ of Total unconstrained who are multiple earners & 48.34 & 45.60 \\
$\%$ of Total unconstrained aged under 25 & 8.60 & 5.05 \\
$\%$ of Total unconstrained aged 25 to 34 & 39.33 & 37.14 \\
$\%$ of Total unconstrained aged 35 to 44 & 27.60 & 30.25 \\
$\%$ of Total unconstrained aged 45 to 54 & 15.31 & 17.14 \\
$\%$ of Total unconstrained aged over 54 & 9.17 & 10.42 \\
\hline
\end{tabular}


Table $3 . \quad$ 1988-91

Logistic Regression, Probability of being over the ceiling - Low Price Regions

Classification Table for low price regions

\begin{tabular}{|r|r|r|r|r|}
\hline & & \multicolumn{3}{|c|}{ Predicted } \\
\hline Observed & & & & $\begin{array}{r}\text { Percentage } \\
\text { Correct }\end{array}$ \\
\hline & .00 & 15035 & 3268 & 82.1 \\
\hline & 1.00 & 4361 & 11925 & 73.2 \\
\hline $\begin{array}{r}\text { Overall } \\
\text { Percentage }\end{array}$ & & & 77.9 \\
\hline
\end{tabular}

Variables in the Equation

\begin{tabular}{|c|c|c|c|c|}
\hline & $\mathrm{B}$ & S.E. & Wald & Sig. \\
\hline Previous Owner & .190 & .057 & 11.3 & .001 \\
\hline Basic Income & .123 & .008 & 253.0 & .000 \\
\hline Other Income & .000 & .000 & 760.9 & .000 \\
\hline Other Income Dummy & .016 & .043 & 0.1 & .713 \\
\hline AGE $<25$ & -.020 & .191 & 0.0 & .915 \\
\hline AGE 25-34 & .476 & .149 & 10.2 & .001 \\
\hline AGE 35-44 & .787 & .146 & 29.0 & .000 \\
\hline AGE 45-54 & .453 & .159 & 8.1 & .004 \\
\hline Income Age $<25$ & .232 & .016 & 215.9 & .000 \\
\hline Income Age 25-34 & .145 & .010 & 227.0 & .000 \\
\hline Income Age35-44 & .057 & .009 & 38.6 & .000 \\
\hline Income Age 45-54 & .017 & .010 & 2.9 & .087 \\
\hline Prev Owner*Age $<25$ & -.277 & .095 & 8.4 & .004 \\
\hline Prev Owner*Age 25-34 & -.160 & .072 & 4.9 & .026 \\
\hline Yorks\&Humber & .138 & .049 & 7.8 & .005 \\
\hline East Midlands & .488 & .052 & 88.1 & .000 \\
\hline North West & .226 & .049 & 21.4 & .000 \\
\hline Scotland & .042 & .053 & 0.6 & .421 \\
\hline West Midlands & .556 & .051 & 119.3 & .000 \\
\hline 1988 & -.362 & .038 & 89.7 & .000 \\
\hline 1989 & -.097 & .040 & 5.8 & .016 \\
\hline 1990 & .007 & .041 & 0.0 & .867 \\
\hline Constant & -4.164 & .137 & 921.0 & .000 \\
\hline
\end{tabular}




\section{8-91}

Logistic Regression, Probability of being over the ceiling - High Price Regions

Classification Table for high price regions

\begin{tabular}{|r|r|r|r|r|}
\hline & & \multicolumn{3}{|c|}{ Predicted } \\
\hline Observed & & & & $\begin{array}{r}\text { Percentage } \\
\text { Correct }\end{array}$ \\
\hline & .00 & 4073 & 3463 & 54.0 \\
\hline & 1.00 & 1422 & 17819 & 92.6 \\
\hline $\begin{array}{r}\text { Overall } \\
\text { Percentage }\end{array}$ & & & & 81.8 \\
\hline
\end{tabular}

Variables in the Equation

\begin{tabular}{|r|c|c|c|c|}
\hline & B & S.E. & Wald & Sig. \\
\hline Previous Owner & .203 & .057 & 12.5 & .000 \\
\hline Basic Income & .092 & .006 & 236.8 & .000 \\
\hline Other Income & .000 & .000 & 340.4 & .000 \\
\hline Other Income Dummy & .201 & .051 & 15.3 & .000 \\
\hline AGE < 25 & 1.585 & .190 & 69.4 & .000 \\
\hline AGE 25-34 & 1.004 & .145 & 48.0 & .000 \\
\hline AGE 45-54 & .626 & .134 & 21.9 & .000 \\
\hline Income Age <25 & .378 & .140 & 7.3 & .007 \\
\hline Income Age 25-34 & .116 & .016 & 54.6 & .000 \\
\hline Income Age35-44 & .066 & .008 & 67.5 & .000 \\
\hline Income Age 45-54 & .024 & .008 & 8.9 & .003 \\
\hline Prev Owner*Age <25 & -.047 & .124 & 0.1 & .705 \\
\hline Prev Owner*Age 25-34 & -.114 & .083 & 1.9 & .168 \\
\hline South East & -.061 & .053 & 1.4 & .245 \\
\hline South West & -.142 & .056 & 6.3 & .012 \\
\hline East Anglia & -.302 & .067 & 20.2 & .000 \\
\hline 1988 & .076 & .044 & 2.9 & .085 \\
\hline 1989 & .237 & .052 & 20.8 & .000 \\
\hline Constant & -2.909 & .120 & 585.9 & .000 \\
\hline & & & & \\
\hline
\end{tabular}


Table 4. 1988-91 In LTV Regression

Diagnostic Statistics

\begin{tabular}{|c|c|}
\hline No. of Observations & 61110 \\
\hline Parameters & 25 \\
\hline Degrees of Freedom & 61085 \\
\hline Adjusted R-squared & 0.294 \\
\hline Model F Test $=1063.20$ & F Prob value $=0.000$ \\
\hline Log Amemiya PrCrt = -1.758 & Akaike Info Crt $=1.080$ \\
\hline \multicolumn{2}{|c|}{$\begin{array}{l}\text { Correlation of regression disturbance and selection criterion (Rho) } \\
=0.36886\end{array}$} \\
\hline
\end{tabular}

Variables in Model

\begin{tabular}{|c|c|c|c|c|}
\hline & Coeff & Std Error & t-Stat & P-value \\
\hline Constant & -3.562 & 0.053 & -67.5 & 0.000 \\
\hline Previous Owner & -0.284 & 0.007 & -40.3 & 0.000 \\
\hline Basic Income & 0.275 & 0.006 & 49.8 & 0.000 \\
\hline Other Income & 0.068 & 0.003 & 23.1 & 0.000 \\
\hline Other Income Dummy & -0.476 & 0.025 & -18.8 & 0.000 \\
\hline Age $<25$ & 0.575 & 0.010 & 54.9 & 0.000 \\
\hline Age 25-34 & 0.501 & 0.009 & 55.7 & 0.000 \\
\hline Age 35-44 & 0.429 & 0.007 & 58.6 & 0.000 \\
\hline Age 45-54 & 0.188 & 0.008 & 23.8 & 0.000 \\
\hline Prev Owner*Age $<25$ & 0.195 & 0.012 & 16.1 & 0.000 \\
\hline Prev Owner*Age35-44 & 0.152 & 0.009 & 17.3 & 0.000 \\
\hline Yorks\&Humber & 0.136 & 0.008 & 16.1 & 0.000 \\
\hline East Midlands & 0.125 & 0.009 & 14.1 & 0.000 \\
\hline North West & 0.149 & 0.008 & 17.8 & 0.000 \\
\hline Scotland & 0.201 & 0.009 & 22.7 & 0.000 \\
\hline West Midlands & 0.095 & 0.009 & 11.0 & 0.000 \\
\hline North & 0.184 & 0.009 & 19.2 & 0.000 \\
\hline South East & 0.004 & 0.007 & 0.5 & 0.626 \\
\hline South West & 0.069 & 0.008 & 8.4 & 0.000 \\
\hline East Anglia & 0.070 & 0.010 & 6.8 & 0.000 \\
\hline 1988 & 0.009 & 0.005 & 1.9 & 0.053 \\
\hline 1989 & -0.009 & 0.005 & -1.7 & 0.079 \\
\hline 1990 & 0.025 & 0.005 & 4.7 & 0.000 \\
\hline T_ABOVE & -6.383 & 0.221 & -28.8 & 0.000 \\
\hline LAMBDA & 0.159 & 0.014 & 11.6 & 0.000 \\
\hline
\end{tabular}




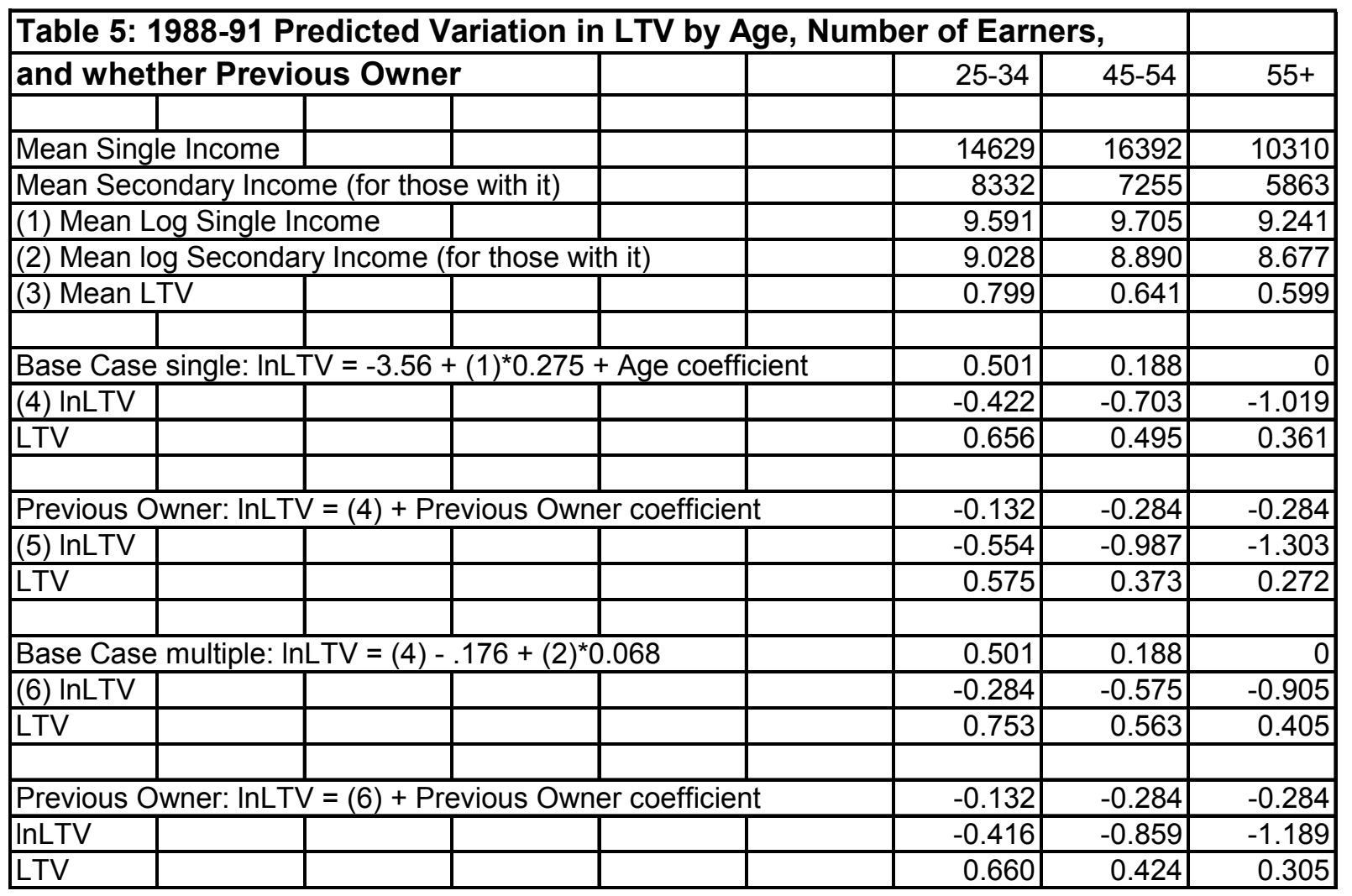


Table 6. 1995-98

Logistic Regression, Probability of being over the ceiling - Low Price Regions

Classification Table for low price areas

\begin{tabular}{|r|r|r|r|r|}
\hline & & \multicolumn{3}{|c|}{ Predicted } \\
\hline Observed & & & & $\begin{array}{r}\text { Percentage } \\
\text { Correct }\end{array}$ \\
\hline & .00 & 4821 & 4689 & 50.7 \\
\hline $\begin{array}{r}\text { Overall } \\
\text { Percentage }\end{array}$ & 1.00 & 1786 & 25913 & 93.6 \\
\hline
\end{tabular}

Variables in the Equation

\begin{tabular}{|c|c|c|c|c|}
\hline & $B$ & S.E. & Wald & Sig. \\
\hline Previous Owner & -0.250 & 0.044 & 32.5 & 0.000 \\
\hline Basic Income & 0.129 & 0.004 & 973.8 & 0.000 \\
\hline Other Income & 0.000 & 0.000 & 364.9 & 0.000 \\
\hline Other Income Dummy & 0.160 & 0.045 & 12.4 & 0.000 \\
\hline AGE $<25$ & 0.306 & 0.210 & 2.1 & 0.145 \\
\hline AGE 25-34 & 1.317 & 0.119 & 121.5 & 0.000 \\
\hline AGE 35-44 & 1.492 & 0.108 & 191.9 & 0.000 \\
\hline AGE 45-54 & 1.056 & 0.107 & 97.6 & 0.000 \\
\hline Income Age < 25 & 0.171 & 0.018 & 90.5 & 0.000 \\
\hline Income Age 25-34 & 0.062 & 0.008 & 66.4 & 0.000 \\
\hline Income Age35-44 & -0.002 & 0.006 & 0.1 & 0.801 \\
\hline Income Age 45-54 & -0.037 & 0.006 & 42.2 & 0.000 \\
\hline Prev Owner*Age $<25$ & -0.235 & 0.151 & 2.4 & 0.120 \\
\hline Prev Owner*Age 25-34 & 0.042 & 0.071 & 0.4 & 0.554 \\
\hline Yorks\&Humber & 0.243 & 0.062 & 15.4 & 0.000 \\
\hline East Midlands & 0.127 & 0.062 & 4.3 & 0.039 \\
\hline North West & 0.235 & 0.061 & 14.8 & 0.000 \\
\hline Scotland & 0.144 & 0.065 & 5.0 & 0.026 \\
\hline West Midlands & 0.236 & 0.062 & 14.3 & 0.000 \\
\hline South West & 0.326 & 0.060 & 29.1 & 0.000 \\
\hline East Anglia & 0.120 & 0.073 & 2.7 & 0.099 \\
\hline 1996 & -0.080 & 0.041 & 3.9 & 0.050 \\
\hline 1997 & -0.064 & 0.040 & 2.5 & 0.112 \\
\hline 1998 & -0.125 & 0.043 & 8.4 & 0.004 \\
\hline Constant & -2.761 & 0.093 & 881.5 & 0.000 \\
\hline
\end{tabular}




\section{5-98}

Logistic Regression, Probability of being over the ceiling - High Price Regions

Classification Table for high price areas

\begin{tabular}{|r|r|r|r|r|}
\hline & & \multicolumn{3}{|r|}{ Predicted } \\
\hline & & & & $\begin{array}{r}\text { Percentage } \\
\text { Correct }\end{array}$ \\
\hline Observed & & .00 & 1.00 & 41.6 \\
\hline & .00 & 1469 & 2059 & 96.3 \\
\hline Overall & 1.00 & 563 & 14674 & 86.0 \\
Percentage & & & & \\
\hline
\end{tabular}

Variables in the Equation

\begin{tabular}{|c|c|c|c|c|}
\hline & $\mathrm{B}$ & S.E. & Wald & Sig. \\
\hline Previous Owner & -0.382 & 0.066 & 33.2 & 0.000 \\
\hline Basic Income & 0.114 & 0.005 & 591.6 & 0.000 \\
\hline Other Income & 0.000 & 0.000 & 98.1 & 0.000 \\
\hline Other Income Dummy & 0.116 & 0.068 & 2.9 & 0.087 \\
\hline AGE $<25$ & 0.479 & 0.400 & 1.4 & 0.231 \\
\hline AGE 25-34 & 1.811 & 0.172 & 111.1 & 0.000 \\
\hline AGE 35-44 & 2.110 & 0.148 & 204.4 & 0.000 \\
\hline AGE 45-54 & 0.877 & 0.147 & 35.4 & 0.000 \\
\hline Income Age < 25 & 0.120 & 0.030 & 16.2 & 0.000 \\
\hline Income Age 25-34 & -0.012 & 0.008 & 2.1 & 0.144 \\
\hline Income Age35-44 & -0.045 & 0.007 & 45.6 & 0.000 \\
\hline Income Age 45-54 & -0.030 & 0.007 & 18.9 & 0.000 \\
\hline Prev Owner*Age < 25 & -0.933 & 0.241 & 15.0 & 0.000 \\
\hline Prev Owner*Age 25-34 & 0.047 & 0.119 & 0.2 & 0.695 \\
\hline South East & -0.145 & 0.050 & 8.5 & 0.004 \\
\hline 1996 & -0.225 & 0.064 & 12.5 & 0.000 \\
\hline 1997 & -0.331 & 0.063 & 27.8 & 0.000 \\
\hline 1998 & -0.311 & 0.068 & 20.7 & 0.000 \\
\hline Constant & -1.441 & 0.115 & 157.2 & 0.000 \\
\hline
\end{tabular}


Table 7. 1995-98 In LTV Regression

Diagnostic Statistics

\begin{tabular}{|l|l|}
\hline No. of Observations & 55974 \\
\hline Parameters & 26 \\
\hline Degrees of Freedom & 55948 \\
\hline Adjusted R-squared & 0.328 \\
\hline Model F Test $=1095.59$ & F Prob value $=0.000$ \\
\hline Log Amemiya PrCrt $=-1.754$ & Akaike Info Crt $=1.084$ \\
\hline $\begin{array}{l}\text { Correlation of regression disturbance and selection criterion (Rho) } \\
=0.17774\end{array}$ \\
\hline
\end{tabular}

Variables in Model

\begin{tabular}{|c|c|c|c|c|}
\hline 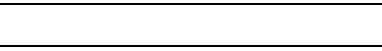 & Coeff & Std Error & t-Stat & P-value \\
\hline Constant & -2.015 & 0.076 & -26.5 & 0.000 \\
\hline Previous Owner & -0.335 & 0.006 & -54.1 & 0.000 \\
\hline Basic Income & 0.196 & 0.007 & 26.5 & 0.000 \\
\hline Other Income & 0.022 & 0.003 & 6.8 & 0.000 \\
\hline Other Income Dummy & -0.189 & 0.029 & -6.6 & 0.000 \\
\hline AGE $<25$ & 0.226 & 0.012 & 18.5 & 0.000 \\
\hline AGE 25-34 & 0.157 & 0.010 & 15.4 & 0.000 \\
\hline AGE 35-44 & 0.189 & 0.008 & 24.9 & 0.000 \\
\hline AGE 45-54 & 0.070 & 0.007 & 10.5 & 0.000 \\
\hline Prev Owner*Age < 25 & 0.112 & 0.018 & 6.1 & 0.000 \\
\hline Prev Owner*Age 25-34 & 0.160 & 0.008 & 19.0 & 0.000 \\
\hline Yorks\&Humber & 0.167 & 0.008 & 20.4 & 0.000 \\
\hline East Midlands & 0.168 & 0.008 & 20.5 & 0.000 \\
\hline North West & 0.159 & 0.008 & 20.0 & 0.000 \\
\hline Scotland & 0.174 & 0.008 & 20.5 & 0.000 \\
\hline West Midlands & 0.117 & 0.008 & 14.4 & 0.000 \\
\hline North & 0.084 & 0.008 & 10.8 & 0.000 \\
\hline South East & 0.120 & 0.010 & 12.2 & 0.000 \\
\hline South West & 0.191 & 0.010 & 19.9 & 0.000 \\
\hline East Anglia & 0.026 & 0.007 & 4.0 & 0.000 \\
\hline 1988 & -0.108 & 0.005 & -19.7 & 0.000 \\
\hline 1989 & -0.126 & 0.005 & -24.3 & 0.000 \\
\hline 1990 & -0.149 & 0.005 & -27.7 & 0.000 \\
\hline T_ABOVE & -14.051 & 0.481 & -29.2 & 0.000 \\
\hline T_BELOW & -62.669 & 1.543 & -40.6 & 0.000 \\
\hline LAMBDA & 0.075 & 0.013 & 5.9 & 0.000 \\
\hline
\end{tabular}




\begin{tabular}{|l|l|r|r|r|r|r|}
\hline Table 8: 1995-98 Predicted Variation in LTV by Age, Number of Earners & \\
\hline and whether Previous Owner & & & & $25-34$ & $45-54$ & $55+$ \\
\hline
\end{tabular}


Table 9. 1995-98 In LTV Regression including Interactions of the Tax penalty Variables with over age 34 Dummies

Diagnostic Statistics

\begin{tabular}{|l|l|}
\hline No. of Observations & 55974 \\
\hline Parameters & 28 \\
\hline Degrees of Freedom & 55946 \\
\hline Adjusted R-squared & 0.334 \\
\hline Model F Test $=1040.62$ & F Prob value $=0.000$ \\
\hline Log Amemiya PrCrt $=-1.762$ & Akaike Info Crt $=1.076$ \\
\hline $\begin{array}{l}\text { Correlation of regression disturbance and selection criterion }(\text { Rho })= \\
0.18709\end{array}$ \\
\hline
\end{tabular}

Variables in Model

\begin{tabular}{|c|c|c|c|c|}
\hline & Coeff & Std Error & t-Stat & P-value \\
\hline Constant & -2.027 & 0.076 & -26.8 & 0.000 \\
\hline Previous Owner & -0.321 & 0.006 & -51.6 & 0.000 \\
\hline Basic Income & 0.191 & 0.007 & 25.9 & 0.000 \\
\hline Other Income & 0.018 & 0.003 & 5.7 & 0.000 \\
\hline Other Income Dummy & -0.147 & 0.029 & -5.1 & 0.000 \\
\hline AGE $<25$ & 0.219 & 0.012 & 17.7 & 0.000 \\
\hline AGE 25-34 & 0.153 & 0.011 & 14.5 & 0.000 \\
\hline AGE 35-44 & 0.266 & 0.009 & 29.5 & 0.000 \\
\hline AGE 45-54 & 0.165 & 0.008 & 19.9 & 0.000 \\
\hline Prev Owner*Age $<25$ & 0.092 & 0.018 & 5.0 & 0.000 \\
\hline Prev Owner*Age 25-34 & 0.145 & 0.008 & 17.1 & 0.000 \\
\hline Yorks\&Humber & 0.169 & 0.008 & 20.8 & 0.000 \\
\hline East Midlands & 0.172 & 0.008 & 21.0 & 0.000 \\
\hline North West & 0.162 & 0.008 & 20.5 & 0.000 \\
\hline Scotland & 0.179 & 0.008 & 21.2 & 0.000 \\
\hline West Midlands & 0.120 & 0.008 & 14.9 & 0.000 \\
\hline North & 0.194 & 0.009 & 20.3 & 0.000 \\
\hline South East & 0.030 & 0.007 & 4.6 & 0.000 \\
\hline South West & 0.092 & 0.008 & 11.8 & 0.000 \\
\hline East Anglia & 0.126 & 0.010 & 12.8 & 0.000 \\
\hline 1996 & -0.105 & 0.005 & -19.3 & 0.000 \\
\hline 1997 & -0.124 & 0.005 & -23.9 & 0.000 \\
\hline 1998 & -0.149 & 0.005 & -27.7 & 0.000 \\
\hline T_ABOVE & -12.047 & 0.532 & -22.6 & 0.000 \\
\hline T_BELOW & -49.397 & 1.676 & -29.5 & 0.000 \\
\hline T_ABOVE\&AGE34 & -2.998 & 0.419 & -7.2 & 0.000 \\
\hline T_BELOW\&AGE34 & -23.429 & 1.182 & -19.8 & 0.000 \\
\hline LAMBDA & 0.078 & 0.013 & 6.2 & 0.000 \\
\hline
\end{tabular}




\begin{tabular}{|l|r|r|r|r|r|r|r|}
\hline Table 10: Predicted Leverage Responses to Removal of Interest \\
\hline Deductibility & & & & & & & \\
\hline & & & & & & & \\
\hline & & over £30000 & under £30000 & & \\
\hline & & T_above & T_above & T_below & T_below & & \\
\hline Coefficients & & -12.05 & -3 & -49.4 & -23.47 & & \\
\hline t-ratio & & -22.6 & -7.2 & -29.5 & -19.8 & & \\
\hline Cumulative Coeff & & -12.05 & -15.05 & -49.4 & -72.87 & & \\
\hline & tax rate & Under 35 & Over 34 & Under 35 & Over 34 & & \\
\hline household share & 0.25 & 0.3 & 0.11 & 0.05 & 0.12 & & \\
\hline & 0.4 & 0.19 & 0.2 & 0.01 & 0.02 & & \\
\hline average loan & 0.25 & 51818 & 49360 & 21696 & 17987 & & \\
\hline & 0.4 & 96440 & 90478 & 18185 & 19304 & & \\
\hline \%decline & 0.25 & 19.0 & 23.2 & 40.5 & 53.5 & & \\
\hline \%decline & 0.4 & 28.6 & 34.4 & 64.6 & 78.4 & & \\
\hline
\end{tabular}

\begin{tabular}{|c|c|c|c|c|c|c|c|c|c|c|}
\hline \multicolumn{9}{|c|}{\begin{tabular}{|l|} 
Table 11: The Ir \\
\end{tabular}} & & \\
\hline 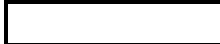 & \multicolumn{2}{|c|}{ Full Deductibility } & \multicolumn{2}{|c|}{ No Decline in v } & \multicolumn{2}{|c|}{$20 \%$ Decline } & \multicolumn{2}{|c|}{ 30\% Decline } & \multicolumn{2}{|c|}{$40 \%$ Decline } \\
\hline Tax Rate & 0.4 & 0.25 & \begin{tabular}{|l|}
0.4 \\
\end{tabular} & 0.25 & 0.4 & 0.25 & 0.4 & 0.25 & 0.4 & 0.25 \\
\hline \multicolumn{11}{|l|}{ Initial v } \\
\hline 0.9 & 0.058 & 0.070 & 0.087 & 0.088 & 0.081 & 0.084 & 0.078 & 0.083 & 0.075 & 0.081 \\
\hline \multirow[t]{3}{*}{0.7} & 0.058 & 0.070 & 0.080 & 0.084 & 0.076 & 0.081 & 0.074 & 0.080 & 0.071 & 0.078 \\
\hline & & & & & & & & & & \\
\hline & & & & & \multicolumn{4}{|c|}{ Percentage Increase in WACC } & & \\
\hline Initial v & & & & & & & & & & \\
\hline 0.9 & & & 50 & 26 & 40 & 21 & 35 & 18 & 30 & 15 \\
\hline 0.7 & & & 39 & 20 & 31 & 16 & 27 & 14 & 23 & 12 \\
\hline
\end{tabular}

Table A: Demand Regressions

Used to Predict Unconstrained Housing Consumption

\begin{tabular}{lcc}
\hline & Demand Regression & Demand Regression \\
& $1988-91$ & $1995-98$ \\
\hline Intercept & -3.368 & -4.221 \\
& $(-74.9)$ & $(-56.4)$ \\
Log of total income & 0.646 & 0.594 \\
& $(152.7)$ & $(138.3)$ \\
Log of marginal cost of housing & -0.396 & -0.252 \\
& $(-83.3)$ & $(-30.8)$ \\
Age of main or first-named borrower & 0.034 & 0.026 \\
Age & $(32.4)$ & $(19.0)$ \\
& -0.0004 & -0.0002 \\
& $(-29.4)$ & $(-15.0)$ \\
$\mathbf{N}$ & & 30,903 \\
Adjusted $\mathrm{R}^{2}$ & 41,441 & 0.419 \\
\hline
\end{tabular}

Dependent variable is log of housing consumption (see text). Figures in parentheses are t-ratios. 